\title{
PALEOMAGNETISM OF SILURIAN AND DEVONIAN VOLCANICS FROM THE CHINGIZ ISLAND ARC, KAZAKHSTAN, AND ITS BEARING ON TECTONIC EVOLUTION OF THE URAL-MONGOL BELT
}

\author{
N. M. Levashova', M. L. Bazhenov', R. Van der Voo², A. V. Abrajevitch ${ }^{3}$ \\ ${ }^{1}$ Geological Institute, Academy of Sciences of Russia, 109017, Moscow, Pyzhevsky Lane, 7, Russia \\ ${ }^{2}$ Department of Geological Sciences, University of Michigan, 48109-1005, Ann Arbor, Michigan, USA \\ ${ }^{3}$ Research School of Earth Sciences, the Australian National University, ACT 0200, 11, Canberra, Australia
}

\begin{abstract}
The tectonic and paleogeographic evolution of the Ural-Mongol belt between the cratons of Baltica, Siberia, and Tarim is the key to the formation of the Eurasian supercontinent during Paleozoic time, but the views on this complicated process remain very disparate and sometimes controversial. Three volcanic formations of the Middle Silurian, Lower-toMiddle Devonian and Middle Devonian age from the southwestern boundary of the Chingiz Range (NE Kazakhstan) yields what are interpreted as primary paleomagnetic directions that help clarify the evolution of the belt. A single-polarity characteristic component in mid-Silurian andesites yields a positive intraformational conglomerate test, whereas dual-polarity prefolding components are isolated from the two Devonian collections. These new data were evaluated together with previously published paleomagnetic results from Paleozoic rocks in the Chingiz Range, and allow us to establish with confidence the hemisphere in which the area was located at a given time. We conclude that NE Kazakhstan was steadily moving northward crossing the equator in Silurian time. These new paleomagnetic data from the Chingiz range also agree with and reinforce the hypothesis that the strongly curved volcanic belts of Kazakhstan underwent oroclinal bending between Middle Devonian and Late Carboniferous time. A comparison of the Chingiz paleolatitudes with those of Siberia shows similarities between the northward motion and rotational history of the Chingiz unit and those of Siberia, which imposes important constraints on the evolving paleogeography of the Ural-Mongol belt.
\end{abstract}

Key words: Ural-Mongol belt, Kazakhstan, Chingiz island arc, Middle Paleozoic, paleomagnetism, oroclinal bending, kinematics of Siberia and Baltica.

Recommended by E.V. Sklyarov 8 September 2011.

Citation: Levashova N.M., Bazhenov M.L., Van der Voo R., Abrajevitch A.V. Paleomagnetism of Silurian and Devonian volcanics from the Chingiz island arc, Kazakhstan, and its bearing on tectonic evolution of the UralMongol belt // Geodynamics \& Tectonophysics. 2011. V. 2. № 3. P. 266-288. doi:10.5800/GT-2011-2-3-0046.

\section{НОВЫЕ ПАЛЕОМАГНИТНЫЕ ДАННЫЕ ПО СИЛУРИЙСКИМ И ДЕВОНСКИМ ВУЛКАНИТАМ ЧИНГИЗСКОЙ ОСТРОВНОЙ ДУГИ КАЗАХСТАНА И ИХ ВКЛАД В ПРЕДСТАВЛЕНИЯ О ТЕКТОНИЧЕСКОЙ ЭВОЛЮЦИИ УРАЛО-МОНГОЛЬСКОГО ПОЯСА}

\author{
Н. М. Левашова ${ }^{1}$, М. Л. Баженов ${ }^{1}$, Р. Ван дер Воํ, А. В. Абражевич ${ }^{3}$
}


${ }^{1}$ Геологический институт РАН, 119017, Москва, Пыжевский пер., 7, Россия

${ }^{2}$ Department of Geological Sciences, University of Michigan, 48109-1005, Ann Arbor, Michigan, USA

${ }^{3}$ Research School of Earth Sciences, the Australian National University, ACT 0200, 11, Canberra, Australia

\begin{abstract}
Аннотация: Тектоническая эволюция Урало-Монгольского подвижного пояса (УМП) многие десятилетия является предметом исследования огромного количества авторов. Однако, несмотря на все усилия, тектонические реконструкции разных авторов различаются самым радикальным образом, а во многом являются взаимоисключающими. Один из способов прояснить ситуацию - получить последовательности разновозрастных палеомагнитных определений и на их основе оценить кинематику ключевых структур УМП. При палеомагнитных исследованиях среднепалеозойских вулканитов Чингизской палеоостровной дуги на северо-востоке Казахстана в андезитах середины силура была выделена первичная компонента намагниченности, что подтверждается положительным тестом галек для внутриформационного конгломерата. В двух среднедевонских объектах также была выделена первичная намагниченность, для которой тест складки и тест обращения положительны. Объединив все имеющиеся данные по этому региону, мы получили последовательность палеомагнитных определений в интервале с позднего кембрия до поздней перми, что позволило уверенно определить, в каком полушарии находилась Чингизская палеодуга. Сделан вывод, что эта структура устойчиво смещалась к северу и пересекла экватор в силуре. Имеющиеся данные так же уверенно указывают на вторичную природу изгиба вулканических поясов Казахстана, имеющих подковообразные очертания. Сравнение этих данных с кривой кажущейся миграции полюса Сибирской платформы позволяет говорить о том, что большую часть палеозоя Чингизская палеодуга двигалась согласованно с Сибирской платформой, что накладывает жесткие ограничения на эволюцию УМП.
\end{abstract}

Ключевые слова: Урало-Монгольский пояс, Казахстан, Чингизская островная дуга, средний палеозой, палеомагнетизм, ороклинальное изгибание, кинематика Сибири и Балтии.

\section{1. ВВЕДЕНИЕ}

Урало-Монгольский складчатый пояс (УМП), расположенный между Восточно-Европейским, Сибирским, Таримским и Северо-Китайским кратонами, является одной из самых протяженных и сложнопостроенных мобильных зон Земли. Различные части пояса совсем не похожи по своим структурно-морфологическим особенностям. Западный сегмент УМП - это Уральская линейная покровно-складчатая область, которая протягивается более чем на 2000 км (рис. 1) и в которой развиты узкие протяженные системы смятых в складки и расчешуенных тектонических покровов. Среди комплексов пород, слагающих Уральскую покровно-складчатую область, выделяются разновозрастные палеозойские островодужные вулканиты, флишевые серии задуговых и преддуговых бассейнов и офиолитовые комплексы.

Восточнее к этому поясу относятся рифейские, салаирские, каледонские и некоторые варисцийские сооружения Казахстана, Алтая, Саян и большей части Монголии (рис. 1). Структура центральной части пояса имеет мозаичный характер. Здесь развиты короткие складчатые зоны с невыдержанными, часто взаимно перпендикулярными простираниями. Широко распространены торцовые сочленения по крупным разломам и крупномасштабные сдвиги. В этой части пояса обычным является тектоническое совмещение докембрийских сиалических массивов, перекрытых кремнистотерригенно-карбонатными чехлами, с палеозойскими островодужными вулканическими сериями, флишевыми толщами и аккреционными комплексами. На юге Урало-Монгольского пояса основными элементами являются линейные покровно-складчатые сооружения, самые крупные из которых - варисцийские Туркестано-Алайская и Джунгаро-Южномонгольская складчатые системы.

Казахстан, вероятно, наиболее сложнопостроенная часть УМП, где мозаичный характер раннепалеозойской структуры наиболее выражен. Среди раннепалеозойских образований широко распространены островодужные комплексы, представленные дифференцированными вулканическими сериями, аккреционные комплексы, представленные олистостромовыми и кремнисто-туфогенными толщами, а также комплексы преддуговых и задуговых бассейнов - флишевые и пестроцветные терригенно-карбонатные толщи.

В средне-позднепалеозойской структуре Казахстана определяющими являются вулканоплутонические пояса Казахстанского пояса [Богданов, 1965], несогласно перекрывающие более древние структуры и имеющие в плане форму подковы (рис. 2). Позднее в среднепозднепалеозойском Казахстанском поясе были выделены позднесилурийско-среднедевонский Казахский пояс и позднепалеозойский Балхаш-Илийский пояс. Развитие первого из них начинается с середины лландовери и продолжается до конца среднего девона [Дегтярев, 1999], и континентальные дифференцированные вулканические серии этого возраста несогласно перекрывают раннепалеозойские комплексы. К 


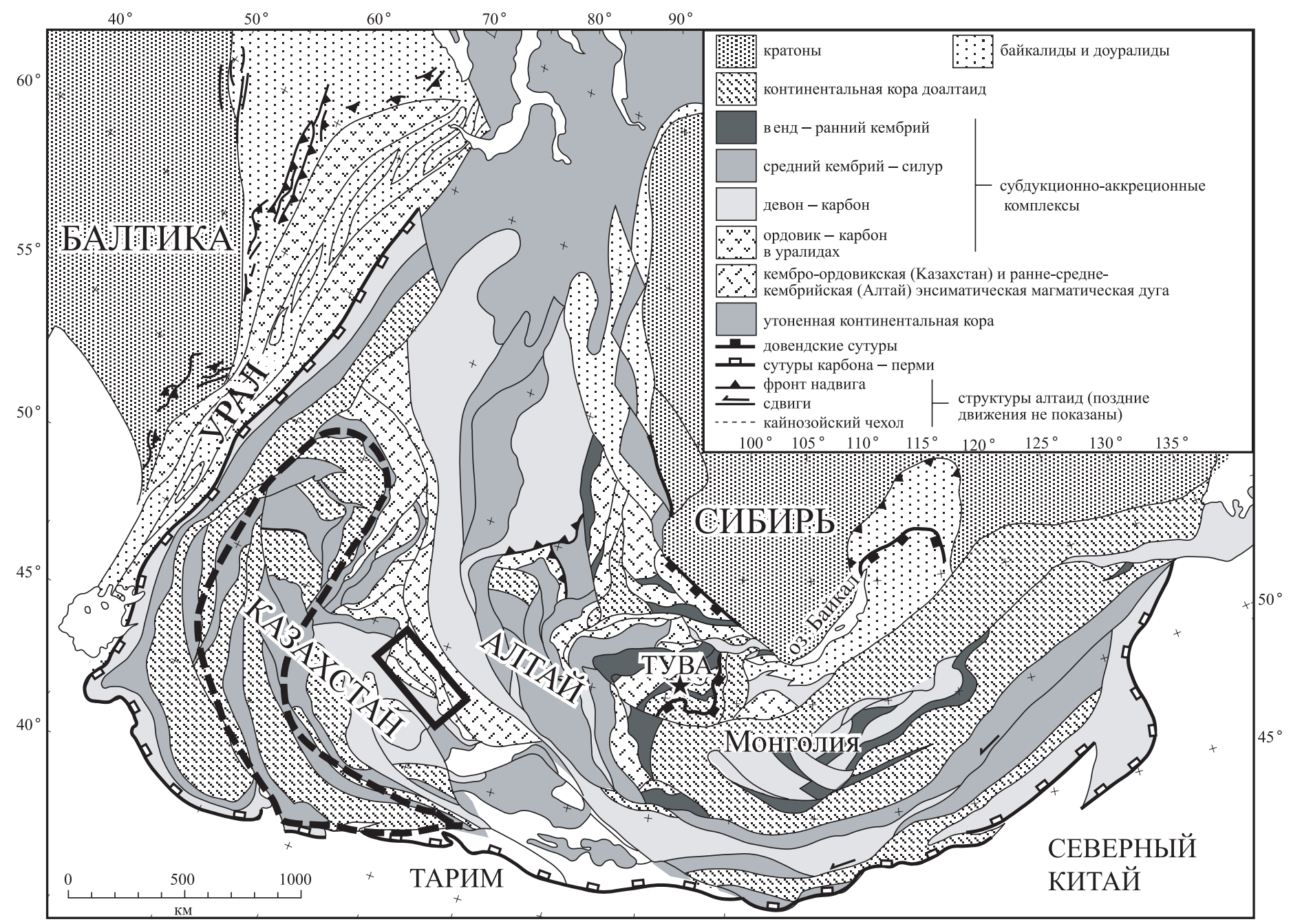

Рис. 1. Схема тектонического строения Урало-Монгольского подвижного пояса (упрощенный вариант Figure 21.18 из [Şengör, Natal'in, 1996]). Прямоугольником показан район Чингизской дуги. Толстой пунктирной линией показана Кокчетав-Северотяньшаньская область согласно [Levashova et al., 2007]. Звездочкой показан район в Туве, где был получен позднесилурийский - раннедевонский палеомагнитный результат [Bachtadse et al., 2000].

Fig. 1. Generalized tectonic map of the Ural-Mongol mobile belt and major surrounding units (modified from Figure 21.18 from [Şengör and Natal'in, 1996]). The rectangle outlines the Chingiz block. The thick dashed line denotes the boundaries of the Kokchetav-North Tien Shan domain (KNTD) as defined by [Levashova et al., 2007]. The star denotes the location of the field area (Tuva) where the Late Silurian - Early Devonian paleomagnetic result was obtained [Bachtadse et al., 2000].

юго-востоку, в пределах Джунгаро-Балхашской складчатой области, вулканические серии замещаются терригенными флишевыми толщами преддуговых прогибов и комплексами аккреционной призмы, а во внешних частях пояса происходит накопление красноцветных терригенных молассовых толщ [Дегтярев, 1999; Тевелев, 2001].

Позднепалеозойский Балхаш-Илийский пояс смещен по отношению к среднепалеозойскому поясу в юго-восточном направлении (рис. 2). Каменноугольные и раннепермские дифференцированные вулканические серии перекрывают более древние преддуговые и аккреционные комплексы. Преддуговые комплексы каменноугольного возраста представлены туфогенны- ми породами и глинисто-кремнистым флишем. В тыловых частях пояса происходило накопление мелководных морских карбонатных, терригенно-карбонатных и угленосных толщ, а в среднем карбоне - перми - пестроцветных терригенных осадков.

Опубликованные модели тектонической эволюции УМП в палеозое поражают разнообразием. Есть группа моделей, для которой базовым является представление о существовании в венде - раннем палеозое Палеоазиатского океана, в котором двигалось множество микроконтинентов, изолированных друг от друга океаническими и задуговыми бассейнами и островными дугами. Главная роль в формировании складчатого пояса отводится процессам открытия и закрытия океа- 


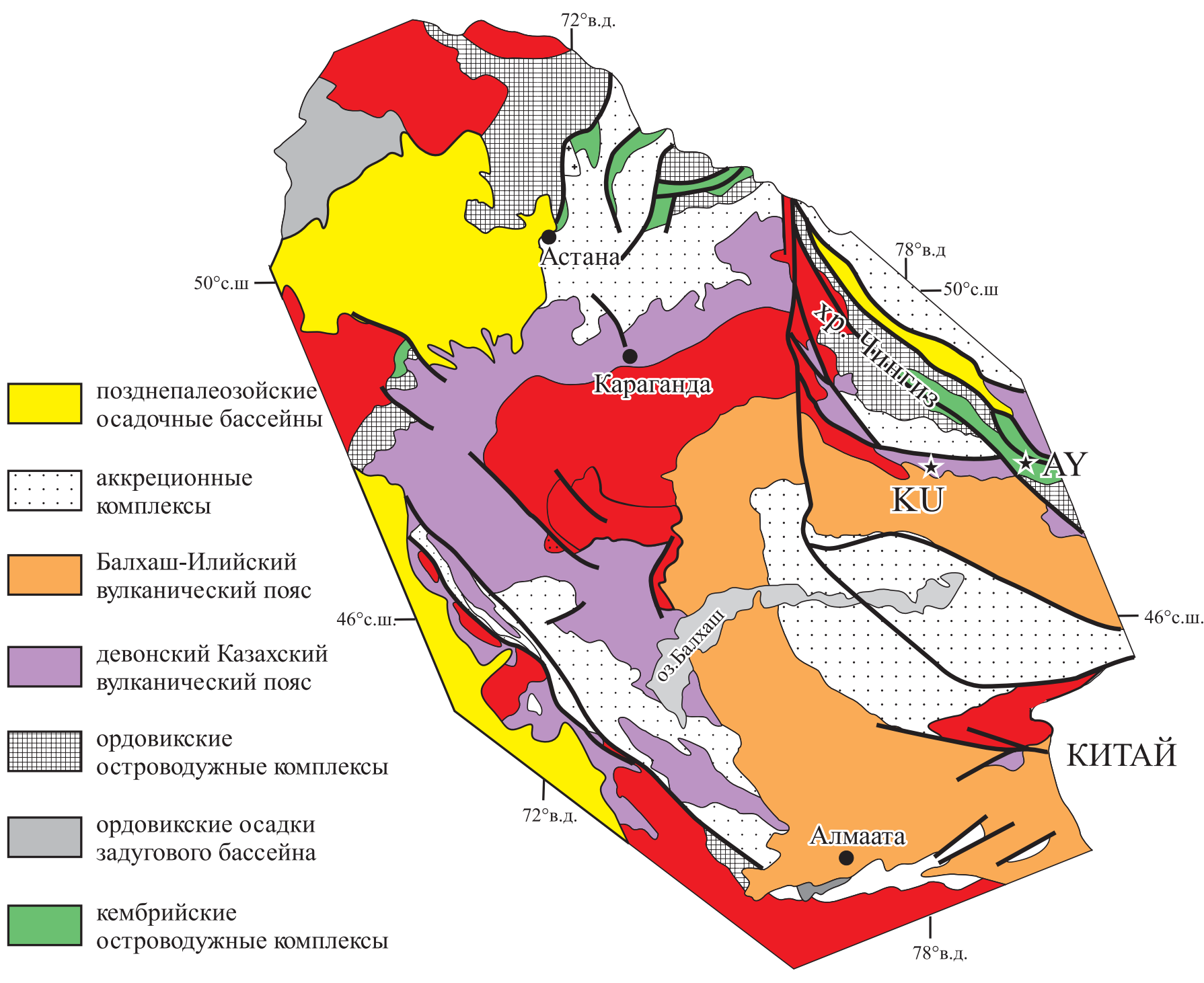

докембрийские породы

Рис. 2. Схематическая геологическая карта Казахстана, упрощенный вариант карты из [Degtyarev, 2003]; БО - бощекульская тектоническая зона. Основные разломы показаны толстыми сплошными линиями. Звездочками показаны районы опробования, обозначенные так же, как в тексте. Красной штриховкой в районе хребта Чингиз обозначен район развития вторичной намагниченности обратной полярности с крутым наклонением (объяснения даны в тексте).

Fig. 2. Schematic geological map of Kazakhstan (simplified after [Degtyarev, 2003]). BO - Boshekul tectonic zone. Main faults are shown as thick solid lines. Stars show the study areas labeled as in the text. The red opaque pattern south of the Chingiz ridge region shows the area wherein secondary reverse overprint magnetization with steep inclination is developed (explanations are given in the text).

океанических и задуговых бассейнов и, как следствие, многоэтапным коллизиям микроконтинентов и островных дуг. Согласно работам [Турманидзе и др., 1991; Моссаковский и др., 1993; Диденко и др., 1994; Куренков и др., 2002], в ордовике - силуре большая часть этих блоков должна была причалить к Сибирской платформе, образуя композитный СибирскоКазахстанский континент. Согласно [Kheraskova et al.,
2003; Filippova et al., 2001], эти блоки должны были столкнуться между собой, образуя Казахстанский континент, который затем двигался независимо от других плит.

Отличительной чертой другой группы моделей является предположение о том, что в венде - раннем палеозое между Европейской и Сибирской платформами существовали протяженные вулканические дуги, кото- 
рые затем претерпели сложные деформации [Şengör, Natal'in, 1996; Yakubchuk et al., 2001, 2002; Пучков, 2000]. Так, в основу модели [Şengör, Natal'in, 1996] положено допущение о том, что в венде - раннем палеозое существовала огромная островная Кипчакская дуга, движение которой согласовано с кинематикой Восточно-Европейской платформы (Балтии) и Сибири. С конца ордовика структура этой системы усложняется за счет причленения к дуге обширных аккреционных комплексов и продольного совмещения отдельных сегментов дуги. В карбоне сформировалась структура, которую можно отождествлять с Казахстанским континентом. В модели [Yakubchuk et al., 2001, 2002] предполагается сосуществование двух параллельных островных дуг, а в моделях [Пучков, 2000; Stampfli, Borel, 2002] раннепалеозойские островные дуги имеют довольно сложную конфигурацию, а процесс их эшелонирования не является в них столь важным, как у [Şengör, Natal'in, 1996]. Само существование столь радикально различающихся моделей говорит о том, что на сегодняшний день неизвестны основные черты развития Урало-Монгольского пояса, а следовательно, и наши представления о процессе формирования суперконтинента Евразии в лучшем случае весьма приблизительны.

Мы полагаем, что такая ситуация в значительной степени возникает из-за малочисленности и зачастую малой надежности палеомагнитных данных по УралоМонгольскому подвижному поясу. Если бы по ключевым структурам этого пояса удалось получить отвечающие современным требованиям палеомагнитные данные определения, а лучше - достаточно длинные временные их последовательности (ряды), это дало бы возможность наложить очень жесткие ограничения на модели тектонической эволюции Урало-Монгольского пояса. Пока такая работа в той или иной степени выполнена только по двум крупным тектоническим единицам УМП.

На западе - юго-западе центральной части УралоМонгольского подвижного пояса в каледонидах Казахстана выделяется крупная Кокчетав-Северотяньшаньская область (КСТШ) (рис. 1). Допозднеордовикские комплексы представлены в КСТШ реликтами докембрийских микроконтинентов, бассейнов с океанической корой и различными островодужными комплексами. В конце ордовика после коллизии микроконтинентов и островных дуг КСТШ превратилась в крупный блок континентальной коры, которую как единое целое имеет смысл выделять с этого времени [Degtyarev, 2003]. Именно тогда различные зоны этой области были прорваны крупными массивами позднеордовикских гранитоидов (крыккудукский, зерендинский комплексы на севере Казахстана, сусамырский комплекс на Северном Тянь-Шане); в дальнейшем значительная часть КСТШ была перекрыта южными ветвями Казахского и Балхаш-Илийского вулканоплутонических поясов (рис. 2). В пределах КСТШ было получено девять палеомагнитных определений в интервале с позднего ордовика по позднюю пермь. Сравнение палеомагнитных данных по КСТШ с кривой кажущейся миграции полюса Балтии показало, что в этом интервале широтные перемещения обоих блоков достаточно согласованны. Этот факт накладывает весьма жесткие ограничения на модели тектонической эволюции УМП в целом и его западной, уральской, части в особенности.

Еще одна крупная тектоническая единица УМП, Чингизская палеоостровная дуга, перекрывается северной ветвью вулканоплутонических поясов (рис. 2). Чингизская островная дуга была активна со среднего кембрия по ранний силур [Дегтярев, 1999]. Ранее в этом районе было получено пять палеомагнитных определений [Levashova et al., 2003a, b; Collins et al., 2003] и было отмечено сходство между наблюденными палеоширотами и пересчитанной для этого района кривой кажущейся миграции полюса Сибирской платформы [Collins et al., 2003]. Было высказано предположение о возможной согласованности движения Чингизской палеодуги и Сибирской платформы. Однако на тот момент данных для сколько-нибудь обоснованных утверждений было недостаточно, что подчеркивалось самими авторами.

В настоящей работе мы представляем новые палеомагнитные определения по среднесилурийским и среднедевонским комплексам из района Чингизской палеодуги. Компиляция всех имеющихся по этой палеодуге палеомагнитных данных позволяет составить последовательность из девяти палеомагнитных определений во временном интервале с позднего кембрия по позднюю пермь.

\section{2. ГЕОЛОГИЧЕСКАЯ ПОЗИЦИЯ ОПРОБОВАННЫХ РАЗРЕЗОВ}

В северо-восточной части Казахстана с северозапада на юго-восток почти на 1500 км протягивается Бощекуль-Чингизская палеоостроводужная система (рис. 2). В ней выделяются Бощекульский и Чингизский сегменты, которые, несмотря на различия в строении, составе и возрасте комплексов, по-видимому, являются частями некогда единой структуры. Бощекульский сегмент сложен кембрийско-раннесилурийскими дифференцированными вулканическими сериями, средневерхнеордовикскими аккреционными комплексами и среднеордовикско-раннесилурийскими флишевыми комплексами. Комплексы Чингизского сегмента протягиваются с северо-запада на юго-восток более чем на 600 км и включают кембрийско-раннесилурийские вулканические серии, средневерхнеордовикские аккреционные комплексы и среднеордовикско-раннесилурийские флишевые комплексы (рис. 2). Чингизский сегмент имеет примерно симметричное строение: в его центральной части распространены преимущественно островодужные вулкани- 
ческие серии, а в юго-западной и северо-восточной преобладают аккреционные и флишоидные комплексы [Дегтярев, 1999].

В Центрально-Чингизской зоне выделяются кембрийско-нижнеордовикские островодужные вулканические и терригенно-туфогенные склоновые комплексы, которые несогласно перекрываются слабодифференцированной андезибазальтовой толщей средневерхнеордовикского возраста. Юго-западнее распространены долландейлские аккреционные комплексы. И они, и вулканиты Центрально-Чингизской зоны перекрываются лландейло-карадокскими карбонатно-терригенными и флишоидными толщами. Далее к югозападу досреднекарадокские аккреционные комплексы несогласно перекрываются средневерхнеордовикскими терригенными и вулканогенными комплексами. Следующая к юго-западу зона сложена досреднеордовикскими аккреционными комплексами, которые перекрываются рифовыми известняками верхнего ордовика, терригенными и терригенно-вулканогенными толщами нижнего - среднего лландовери - венлока. Островодужные комплексы представлены лавами и туфами андезитового и базальтового состава с прослоями терригенных пород. В строении самой западной зоны участвуют фрагменты нижне-, средне- и верхнекембрийских, нижне- и среднеордовикских базальтовых и кремнисто-базальтовых, а также нижнесреднеордовикских кремнистых толщ [Дегтярев, 1999].

Из вышеизложенного следует, что Чингизская островодужная система была активна со среднего кембрия по ранний силур включительно, то есть около ста миллионов лет. Аккреционные комплексы, сформировавшиеся в кембрии - раннем ордовике, либо не сохранились, либо никогда не существовали, так что для этого интервала времени нельзя определить направление субдукции под Чингизскую островную дугу. К юго-западу от Центрально-Чингизской зоны широко распространены аккреционные комплексы, сформировавшиеся с аренига по нижний силур. С северовостока на юго-запад аккреционные комплексы и склоновые отложения заметно омолаживаются. В том же направлении начиная со среднего ордовика происходит омоложение вулканических надсубдукционных комплексов [Дегтярев, 1999].

По всей видимости, начиная с лланвирна вулканический фронт Чингизской островной дуги постепенно мигрировал на юго-запад. В каждом временном интервале перед фронтом дуги накапливались аккреционные и склоновые комплексы, которые затем перекрывались более молодыми островодужными вулканическими сериями. Все это время субдукция под Чингизскую островную дугу шла с юго-запада (в современной системе координат). К концу раннего силура субдукция под Чингизскую островную дугу прекращается, затухает вулканизм и перестают накапливаться аккреционные комплексы [Дегтярев, 1999].
В девоне разновозрастные комплексы Чингизской палеодуги частично перекрываются вулканитами северной ветви Казахского вулканического пояса, причем простирания этих структур почти параллельны (рис. 2). Вулканическая активность в Казахском поясе здесь продолжалась с середины локховского яруса до живета [Щеголева и др., 1993], а проявления позднедевонского вулканизма очень редки. Вулканическая активность возобновилась в визейское время и продолжалась до конца перми. Комплексы позднепалеозойского Балхаш-Илийского вулканического пояса в самой юго-восточной части Чингизской островодужной системы перекрывают и структуры Чингизской дуги, и комплексы Казахского пояса (рис. 2).

Многочисленные угловые несогласия фиксируются в разрезах Чингизской палеодуги и северной ветви Казахского и Балхаш-Илийского вулканических поясов. Видимо, регион был затронут несколькими этапами деформаций, которые происходили в послераннесилурийское и послеживетское время, в визе и в поздней перми [Дегтярев, Рязанцев, 1993]. Масштабы разных этапов деформаций сильно варьируются в пределах региона.

Нами были изучены среднесилурийские вулканиты Чингизской дуги и среднедевонские вулканиты северной ветви Казахского вулканического пояса, перекрывающего комплексы Чингизской дуги на двух участках (рис. 2).

Участок AY (48.0 с.ш., $80.7^{\circ}$ в.д.). В горах Каракунгей был опробован моноклинальный разрез, сложенный андезитами верхней части доненжальской свиты. Нижняя часть свиты представлена красноцветными песчаниками и алевролитами с прослоями кремнистых туфов, в средней части появляются прослои известняков, а в верхней присутствуют базальты и андезиты. Возраст средней части свиты по брахиоподам, кораллам и граптолитам определяется как поздний венлок - ранний лудлов [Тектоника Казахстана, 1982]. Вероятно, вулканиты верхней части свиты имеют венлокский возраст. Нами было опробовано 13 потоков андезитов и пачка красноцветных алевролитов. В двух прослоях внутриформационных конгломератов было отобрано 20 галек андезитов.

Участок KU (48.3ㄷ.ш., 78.3 ${ }^{\circ}$ в.д.). В Предчингизье дагандалинская свита живетского возраста ограничена в подошве и кровле поверхностями размыва. Внизу она представлена базальтами, андезибазальтами и диабазами, а выше - пестроцветными песчаниками, туфопесчаниками, туфами и лавами, преимущественно андезитового состава. Обильные остатки наземной флоры по всему разрезу определяют возраст отложений [Тектоника Казахстана, 1982]. Палеомагнитные данные по небольшому (несколько потоков) моноклинальному обнажению дагандалинской свиты были ранее приведены в работе [Levashova et al., 2003a, b]. В том же районе мы опробовали еще 13 потоков базальтов с различными залеганиями из нижней части свиты. 


\section{3. МЕТОДЫ ЛАБОРАТОРНЫХ ИССЛЕДОВАНИЙ}

В обнажениях вручную отбирались штуфы, ориентированные горным компасом, из которых выпиливались кубики ребром 20 мм. Отбор велся по сайтам, причем в качестве сайта рассматривался либо лавовый поток, либо пачка осадочных пород мощностью несколько метров. Коллекции изучались в палеомагнитных лабораториях ГИН РАН в Москве и Мичиганского университета в Анн Арборе. Все образцы были подвергнуты ступенчатому (до 20 шагов) температурному размагничиванию вплоть до $680{ }^{\circ} \mathrm{C}$. В Москве размагничивание проводилось в самодельной печи с двухслойным пермаллоевым экраном с остаточным полем около 10 нТ. Намагниченность измерялась на спинмагнитометре JR-4 с уровнем шума 0.05 мA/м, помещенном в кольца Гельмгольца, что уменьшило влияние магнитного поля Земли в несколько десятков раз. В Анн Арборе ступенчатая термочистка проводилась в печи марки Analytical Services TD-48, а намагниченность измерялась на криогенном магнитометре 2G Enterprises. И печь, и магнитометр были помещены в немагнитную комнату.

Результаты прогревов были представлены в виде ортогональных диаграмм [Zijderveld, 1967]. Для определения направлений компонент намагниченности использовались линейные участки траектории, включающие не менее трех последовательных нагревов [Kirschvink, 1980]. Данные по образцам из каждого сайта осреднялись, и полученные таким образом средние вектора по сайтам использовались для вычисления среднего направления всей толщи. В тех сайтах, где не удавалось полностью разделить компоненты намагниченности, для вычисления среднего направления по сайтам объединялись направления компонент и круги перемагничивания [McFadden, McElhinny, 1988]. В некоторых сайтах вообще не удалось выделить высокотемпературную компоненту в чистом виде, а полученные при размагничивании круги перемагничивания пересекаются под острыми углами, что не позволяет уверенно определить точку их пересечения. В таких случаях вычислялся средний круг перемагничивания для сайта, а далее для вычисления общего среднего направления для коллекции применялся тот же подход [McFadden, McElhinny, 1988], но уже к совокупности средних по сайтам векторов и кругов перемагничивания. При обработке данных использовалось программное обеспечение С.В. Шипунова, Ж.-П. Конье [Cogné, 2003] и Р. Энкина.

\section{4. РЕЗУЛЬТАТЫ}

\section{1. ВУЛКАНИТЫ «СРЕДНЕГО» СИЛУРА (УЧАСТОК АУ)}

Почти во всех образцах темно-серых андезитов, после удаления при температурах $200-250{ }^{\circ} \mathrm{C}$ небольшой по величине низкотемпературной компоненты намагниченности, выделяется прямолинейная, спадающая в начало координат характеристическая компонента намагниченности (ChRM) (рис. 3, $a, c)$. Напротив, в кирпично-красных андезитах низкотемпературная компонента резко преобладает и сохраняется до несколько более высоких температур, однако во многих образцах ChRM все же удалось выделить (рис. $3, b$ ). Во всех сайтах направления ChRM хорошо сгруппированы, и среднее направление намагниченности по всей коллекции определяется с хорошей точностью (табл. 1). Если судить по блокирующим температурам, носителем ChRM может быть как магнетит, так и гематит, причем направления «магнетитовой» и «гематитовой» компонент совпадают (рис. 3, $a, c$ ).

Залегания в опробованном разрезе меняются мало, и хотя максимальная сходимость данных достигается при $100 \%$ распрямления слоев, тест складки не дает статистически значимого результата (табл. 1 , рис. $4, a$, b).

В 13 из 20 отобранных галек характеристики размагничивания такие же, как во вмещающих породах (рис. $3, d$ ). В оставшихся семи образцах есть среднетемпературная компонента и высокотемпературная компонента, спадающая в начало координат (ChRM) (рис. 3, e). Для ChRM из всех 20 галек нормализованный вектор-результант равен 0.165 , что много меньше критического значения 0.358 [Mardia, 1972]. Таким образом, тест галек, выполненный по внутриформационным конгломератам, является положительным (рис. $4, c)$, а ChRM в вулканитах «среднего» силура можно достаточно уверенно считать первичной.

\section{2. ЖИВЕТСКИЕ БАЗАЛЬТЫ (ОБЪЕКТ КU)}

В четырех из тринадцати опробованных сайтов не удалось выделить стабильной компоненты намагниченности. В оставшихся девяти низкотемпературная компонента намагниченности, направленная по современному полю, удаляется при температуре 200-250 после чего в большинстве образцов можно выделить еще две составляющих. Компонента А выделяется в температурном интервале от $200-250^{\circ}$ до $500-530^{\circ}$. В некоторых образцах это единственная компонента, которую удается выделить (рис. $5, a, b$ ). В остальных образцах на высоких температурах удается выделить еще одну компоненту В, что хорошо видно на ортогональных диаграммах (рис. 5, $c, d$ ) и стереограммах (рис. $5, b$ ). Однако не во всех образцах компоненты А и В удается полностью разделить, даже если на ортогональной диаграмме выделяются два прямолинейных отрезка. Например, аномальное направление среднетемпературной компоненты в образце m9202 (рис. 5, d), вероятно, объясняется перекрытием спектров блокирующих температур компонент А и В (А\&B на рис. $5, c, d)$. Тем не менее средние направления обеих компонент по сайтам или средние по сайтам круги пере- 

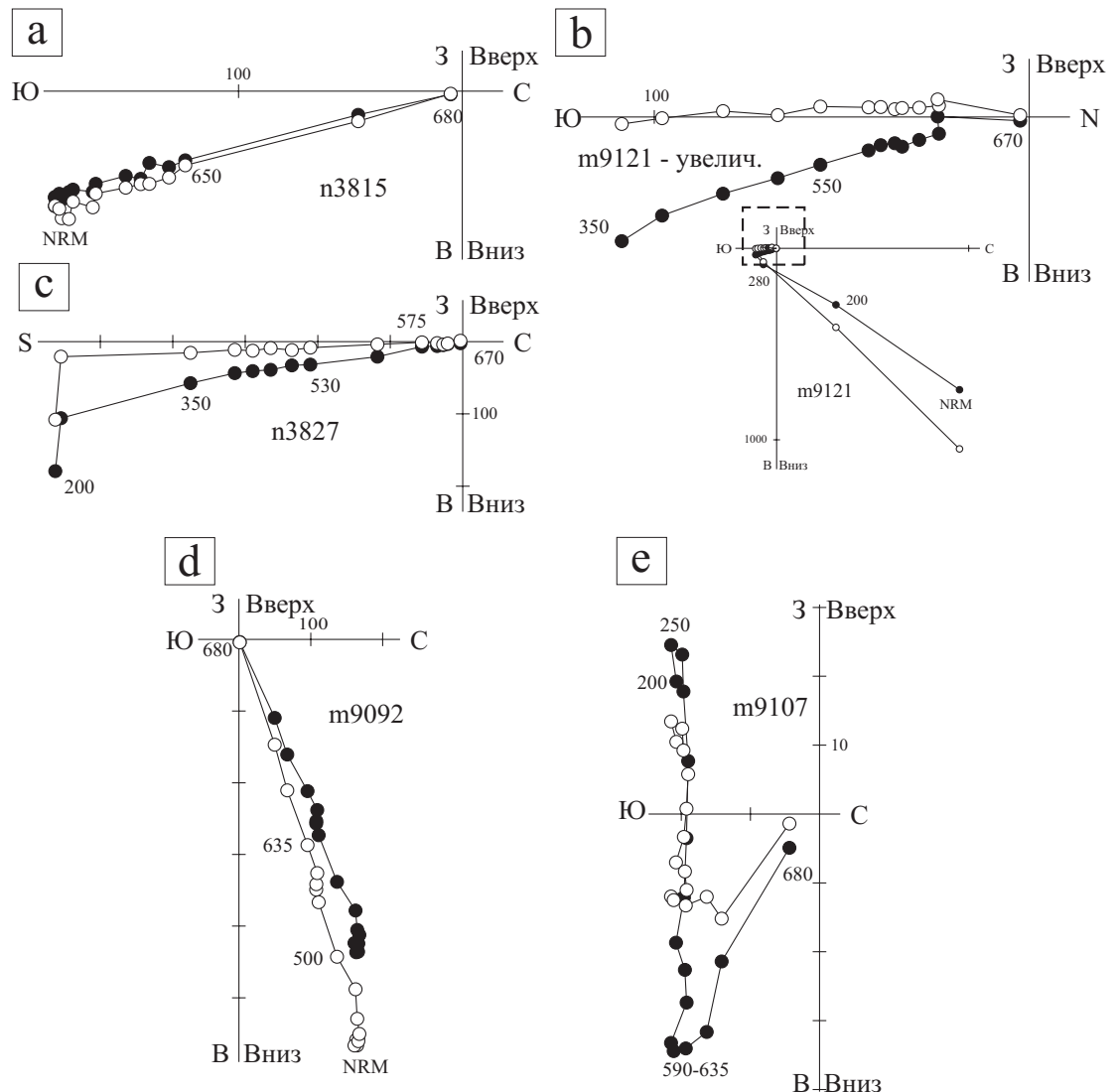

Рис. 3. Примеры диаграмм Зийдервельда для силурийских пород объекта АҮ в древней системе координат: $a-c-$ андезитовые потоки; $d$, $e$ - гальки из внутриформационных конгломератов. Залитыми (незалитыми) символами обозначены проекции на горизонтальную (вертикальную) плоскость. Температуры в градусах Цельсия, величина намагниченности в $\mathrm{mA} / \mathrm{m}$. Для наглядности, начальные точки на некоторых диаграммах опущены.

Fig. 3. Representative thermal demagnetization plots of the Silurian rocks from locality AY, in stratigraphic coordinates: $a-c-$ andesite flows; $d, e-$ cobbles from an intraformational conglomerate. Full (open) circles represent vector endpoints projected onto the horizontal (vertical) plane. Temperature steps are in Celsius degrees. Magnetization intensities are in $\mathrm{mA} / \mathrm{m}$. For clarity, NRM points are omitted from some plots.

T а б л и ц а 1. Направления характеристической компоненты в силурийских породах объекта АY

$\mathrm{T}$ a b l e 1. Directions of characteristic component in the Silurian rocks from locality AY

\begin{tabular}{|c|c|c|c|c|c|c|c|c|c|c|}
\hline \multirow[t]{2}{*}{$\mathrm{S}$} & \multirow[t]{2}{*}{$\mathrm{N} / \mathrm{N}_{0}$} & \multicolumn{5}{|c|}{ Современная система координат } & \multicolumn{4}{|c|}{ Древняя система координат } \\
\hline & & A & $\mathrm{D}^{\circ}$ & $\mathrm{I}^{\circ}$ & $\mathrm{k}$ & $\alpha_{95}{ }^{\circ}$ & $\mathrm{D}^{\circ}$ & $\mathrm{I}^{\circ}$ & $\mathrm{k}$ & $\alpha_{95}{ }^{\circ}$ \\
\hline M9066 & $7 / 7$ & $124 / 20$ & 153.4 & 29.3 & & & 149.9 & 11.5 & 18 & 14.9 \\
\hline N3801 & 7/7 & $124 / 20$ & 168.6 & 35.2 & & & 161.7 & 20.0 & 50 & 8.6 \\
\hline M9073 & $6 / 5$ & $135 / 45$ & 198.2 & 61.8 & & & 163.6 & 28.2 & 25 & 16.1 \\
\hline M9079 & $12 / 7$ & $135 / 45$ & 206.9 & 49.9 & & & 176.9 & 23.6 & 41 & 9.6 \\
\hline M9111 & $6 / 6$ & $135 / 45$ & 192.8 & 21.1 & & & 187.5 & -5.6 & 40 & 10.8 \\
\hline M9117 & $7 / 7$ & $135 / 45$ & 182.1 & 31.8 & & & 173.6 & -2.1 & 285 & 3.6 \\
\hline N3808 & $6 / 6$ & $134 / 39$ & 184.0 & 60.8 & & & 158.6 & 23.0 & 75 & 7.8 \\
\hline N3814 & $6 / 6$ & $134 / 39$ & 184.5 & 55.2 & & & 162.2 & 18.6 & 151 & 5.5 \\
\hline N3820 & $6 / 6$ & $135 / 45$ & 186.5 & 55.5 & & & 163.1 & 19.4 & 38 & 11.0 \\
\hline N3826 & $7 / 7$ & $135 / 45$ & 179.8 & 35.9 & & & 169.8 & 0.5 & 194 & 4.3 \\
\hline N3833 & $6 / 6$ & $135 / 45$ & 204.2 & 38.4 & & & 184.0 & 14.0 & 123 & 6.1 \\
\hline N3839 & $7 / 7$ & $135 / 45$ & 175.7 & 42.3 & & & 163.9 & 4.6 & 139 & 5.1 \\
\hline MEAN & $(12 / 12)$ & & 183.7 & 44.1 & 22 & 9.5 & 168.0 & 13.2 & 28 & 8.4 \\
\hline
\end{tabular}

П р и м е ч а н и е. $\mathrm{S}$ - номера точек опробования; $\mathrm{N} / \mathrm{N}_{0}$ - число образцов (сайтов), отобранных в каждом сайте/использованных для анализа; А - средний по сайту азимут падения/угол падения; D - склонение; I - наклонение; $\mathrm{k}$ - кучность; а95 - радиус круга доверия [Fisher, 1953].

$\mathrm{N}$ o t e. S - sampling sites; $\mathrm{N} / \mathrm{N}_{0}$ - the number of samples (sites) studied/accepted; A - site-mean azimuth of dip/dip angle; D - declination; I -inclination; $\mathrm{k}$ - concentration parameter; $\mathrm{a}_{95}$, - radius of confidence circle [Fisher, 1953]. 


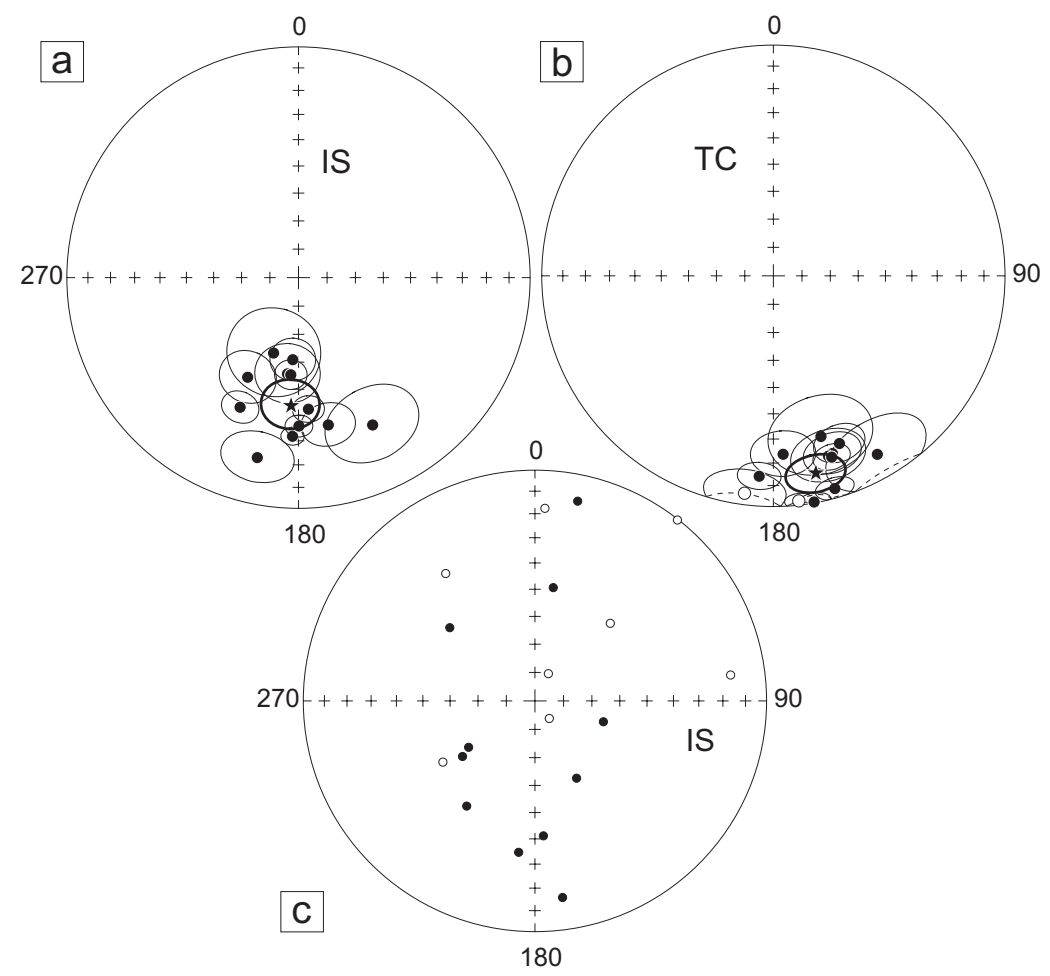

Рис. 4. Стереограмма средних направлений намагниченности по сайтам для силурийских вулканитов объекта АҮ. Кружками показаны средние направления намагниченности по сайтам с кругами доверия (тонкие линии) в современной $(a)$ и древней $(b)$ системах координат. Общее среднее показано звездочкой, его круг доверия - толстой линией; $c$ - направления высокотемпературной компоненты намагниченности, полученные для галек из внутриформационных конгломератов. Залитые (незалитые) кружки и сплошные (пунктирные) линии спроектированы на нижнюю (верхнюю) полусферу.

Fig. 4. Stereoplots of site-mean directions (dots) of the high-temperature component with associated confidence circles (thin lines) in the Silurian volcanic rocks from locality AY, $(a)$ in situ (IS) and $(b)$ after tilt correction (TC). The star with the associated confidence circle (thick line) shows the overall mean directions of the characteristic remanence; $c$ - HTC directions are obtained for cobbles from an intraformational conglomerate. Filled (open) symbols and solid (dashed) lines are projected onto the lower (upper) hemisphere.

магничивания (рис. $5, e$ ) определяются с достаточной точностью (табл. 2). Мы объединили полученные данные с данными по пяти сайтам из тех же пород, опубликованные в работе [Levashova et al., 2003a].

Компонента А хорошо сгруппирована в современной системе координат, а после перевода в древнюю систему ее кучность уменьшается в три раза (табл. 2, рис. $6, a, b)$, то есть компонента А является послескладчатой. Средние направления по сайтам и пересечения кругов перемагничивания компоненты В формируют на стереограмме две приблизительно антиподальные группы (рис. $6, c, d$ ). Кажется логичным считать, что эти две группы соответствуют намагниченности двух полярностей, средние направления которых различаются на $11.7^{\circ} \pm 13.8^{\circ}$, то есть тест обращения положительный. Средние направления по сайтам лучше сгруппированы в древней системе координат, однако тест складки статистически значимого результата не дает. Мы считаем, что компоненту В с достаточной степенью уверенности можно рассматривать как первичную компоненту намагниченности.

\section{3. ПАЛЕОМАГНИТНЫЕ ДАННЫЕ ПО РАЙОНУ ЧИНГИЗСКОЙ ПАЛЕОДУГИ}

С начала 1990-х годов опубликовано несколько палеомагнитных результатов для палеозойских комплексов Чингизской палеодуги и перекрывающих ее вулканических поясов (табл. 3).

В верхнекембрийских андезитах (CL) и нижнеордовикских (аренигских) красноцветах (ОЕ) из центральной части Чингизской палеодуги выделены доскладчатые и предположительно первичные компоненты намагниченности [Collins et al., 2003].

В 30-40 км к юго-западу от объектов CL и OE были изучены нижнесилурийские вулканиты (SI), первичность высокотемпературной компоненты в которых подтверждена тестом обращения, тестом складки и тестом галек из внутриформационных конгломератов [Levashova et al., 2003a].

В верхнесилурийских красноцветах (G2) выделена предположительно древняя намагниченность, но этот результат базируется всего на 12 образцах и не подтвержден полевыми тестами [Grishin et al., 1997]. 
a

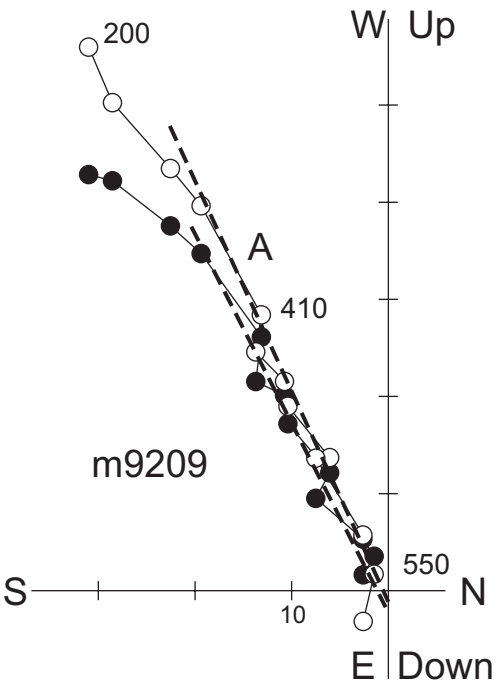

b

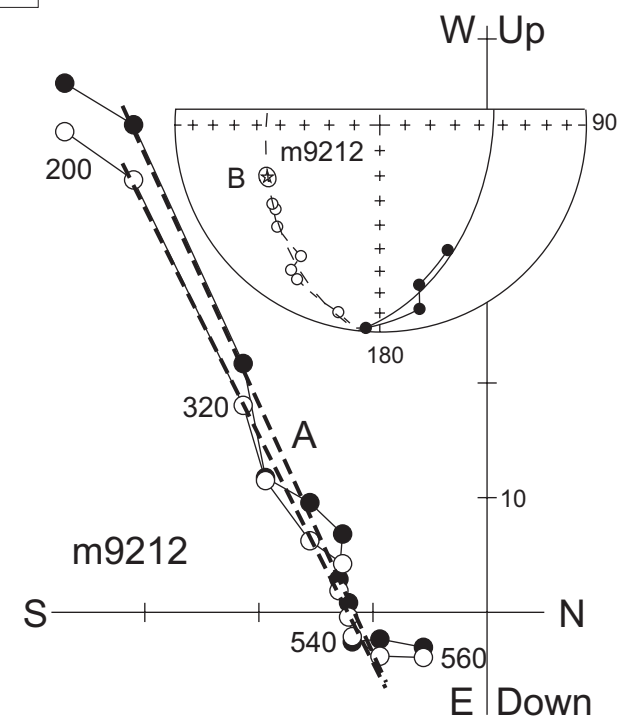

d
C

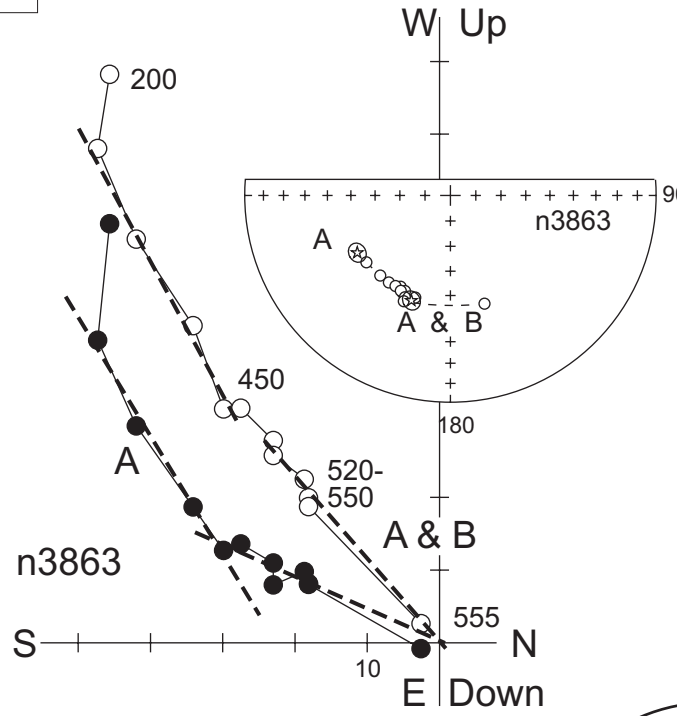

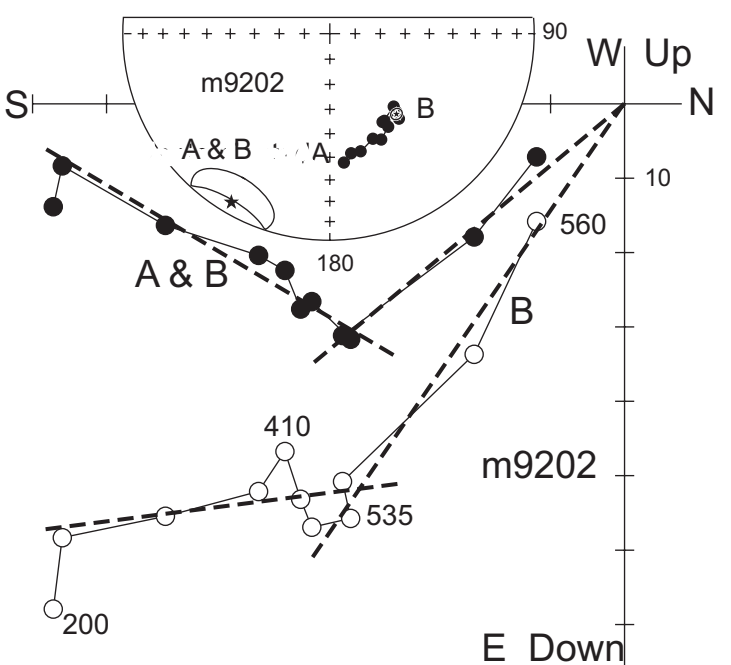

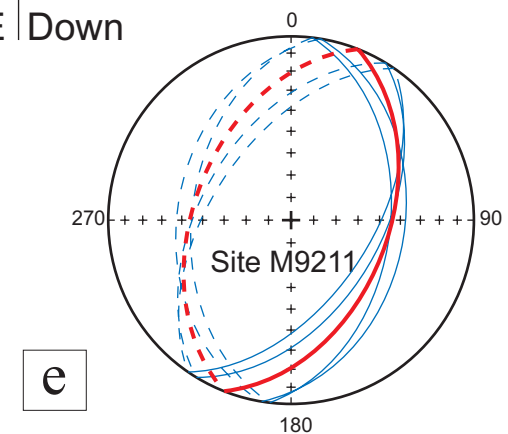

Рис. 5. $a-d$ - представительные диаграммы Зийдервельда и стереограммы измеренных направлений намагниченности и выделенных компонент в живетских вулканитах участка KU в стратиграфических координатах. На диаграммах выделенные компоненты (толстые пунктирные линии) обозначены как в тексте. Звездочками обозначены направления выделенных компонент с соответствующими кругами доверия (тонкие линии); $e$ - пример определения среднего круга перемагничивания для сайта (толстая красная линия) по субпараллельным кругам перемагничивания отдельных образцов (тонкие синие линии). Остальные обозначения для диаграмм и стереограмм как на рисунках 3 и 4 соответственно.

Fig. 5. $a-d$ - representative thermal demagnetization plots and stereonets of vector end-points and isolated components in the Givetian volcanics from locality KU in stratigraphic coordinates. Thick dashed lines denote isolated components labeled as in the text; A and B stand for linear segments, where component isolation was not achieved because of overlapping unblocking spectra. Stars in stereonets are the best estimates of the (A or B) component directions with associated confidence circles (thin lines); $e$ - an example of the computation of the mean remagnetization circle (thick red line) from several near-parallel sample remagnetization trajectories (thin blue lines). Other notation for the orthogonal plots and stereonets as in Figures 3 and 4, respectively. 

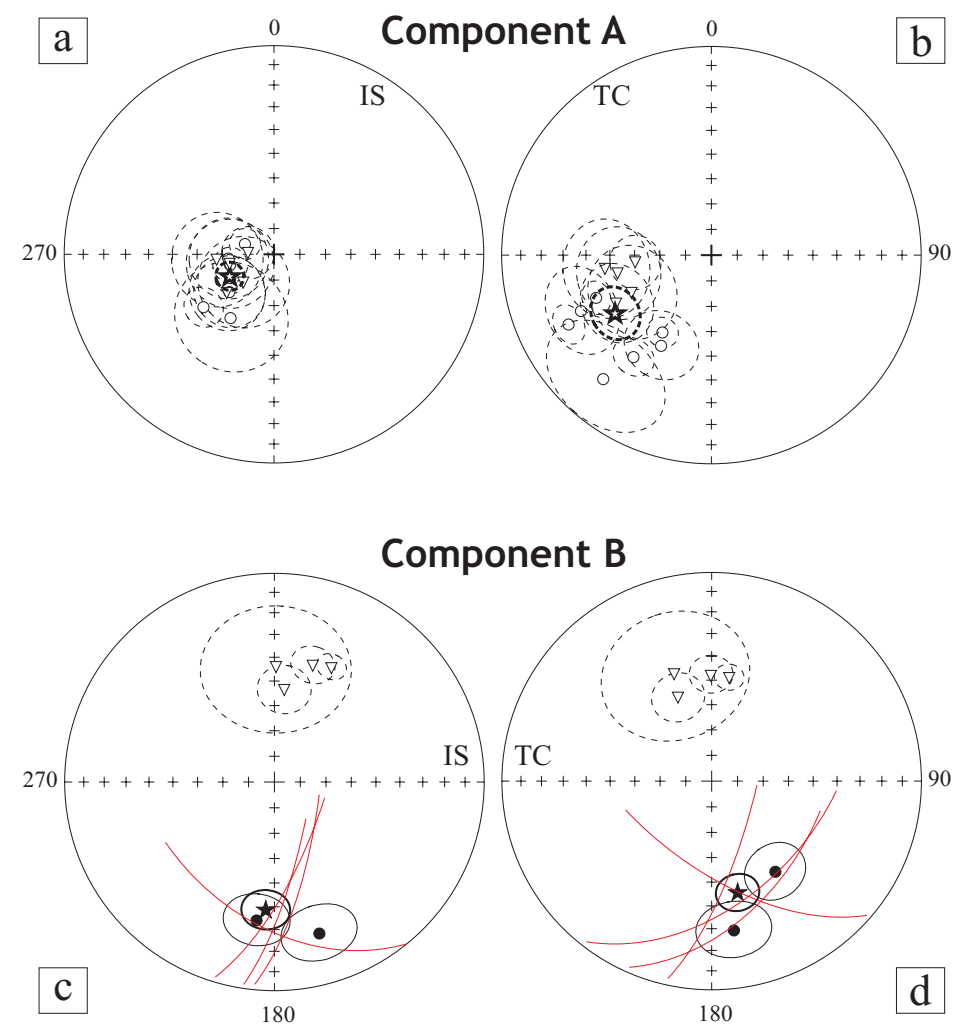

Рис. 6. Средние по сайтам направления намагниченности и круги перемагничивания (красные линии) в живетских вулканитах объекта КU для $(a, b)$ - среднетемпературной компоненты A; $(c, d)$ - для высокотемпературной компоненты В в $(a, c)$ современной (IS) и $(b, e)$ древней (TC) системах координат. Средние вектора по сайтам из [Levashova et al., 2003a] и этой работы показаны треугольниками и кружками соответственно с кругами доверия (тонкие линии). Остальные обозначения как на рис. 4.

Fig. 6. Site-mean directions and site-mean remagnetization circles (red lines) in the Givetian volcanics of locality KU for intermediate-temperature component $\mathrm{A}(a, b)$ and high-temperature component $\mathrm{B}(c, d)$ in situ $(a, c)$ and after tilt correction $(b, e)$. Triangles and circles show results from [Levashova et al., 2003a] and this study, respectively, with associated confidence circles (thin lines). Other notation as in Figure 4.

Опубликованные в этой же работе данные (G1) по среднедевонским вулканитам Казахского пояса также базируются на девяти образцах и не подтверждены полевыми тестами (табл. 3). Мы не стали исключать эти данные из рассмотрения, но следует учитывать их невысокую надежность.

Первичность намагниченности в среднедевонских вулканитах другого участка (KN\&DG) подтверждена тестом складки и тестом обращения [Levashova et al., 2009].

Объект KN изучался ранее В.С. Буртманом с соавторами [1998]. Результат подтвержден тестом складки и тестом обращения. Нас, однако, обескуражил тот факт, что, изучая те же самые породы, мы получили совершенно другое направление высокотемпературной компоненты намагниченности [Levashova et al., 2009]. Более того, направление, приведенное в работе [Burtman et al., 1998], статистически неотличимо от направления вторичной среднетемпературной компоненты намагниченности как в вулканитах объекта KN, так и в других объектах Чингизской палеодуги (под- робнее о региональном перемагничивании ниже). В конечном итоге мы решили воздержаться от использования данных из работы [Burtman et al., 1998].

Результаты по двум разрезам верхнепермских вулканитов Балхаш-Илийского пояса подтверждены тестом складки (РА и РВ, табл. 3) [Levashova et al., 2003б].

\section{4. ВТОРИЧНАЯ НАМАГНИЧЕННОСТЬ}

Вторичная компонента намагниченности выделяется на ряде объектов Чингизской палеодуги на протяжении примерно 300 км (см. рис. 2). Послескладчатая компонента намагниченности А из живетских вулканитов объекта KU статистически неотличима от послескладчатой компоненты в нижнесилурийских вулканитах объекта SI [Levashova et al., 2003a] и синскладчатой компоненты объекта KN\&DG [Levashova et al., 2009]. Вполне логично предположить, что перемагничивание произошло во всем районе примерно одновременно. Однако возраст перемагничивания не 
T а б л и ц а 2. Направления палеомагнитных компонент в живетских вулканитах объекта KU

$\mathrm{T}$ a b l e 2. Directions of paleomagnetic components in the Givetian volcanics from locality KU

\begin{tabular}{|c|c|c|c|c|c|c|c|c|c|c|}
\hline \multirow[t]{2}{*}{$\mathrm{S}$} & \multirow[t]{2}{*}{$\mathrm{N} / \mathrm{N}_{0}$} & \multicolumn{4}{|c|}{ Современная система координат } & & \multicolumn{4}{|c|}{ Древняя система координат } \\
\hline & & $\mathrm{A}$ & $\mathrm{D}^{\circ}$ & $\mathrm{I}^{\circ}$ & $\mathrm{k}$ & $\alpha_{95}^{\circ}$ & $\mathrm{D}^{\circ}$ & $\mathrm{I}^{\circ}$ & $\mathrm{k}$ & $\alpha_{95}{ }^{\circ}$ \\
\hline M9198 & $7 / 4$ & $63 / 48$ & 261.2 & -72.5 & & & 249.0 & -25.2 & 183 & 6.8 \\
\hline M9211 & $6 / 6$ & $62 / 41$ & 294.6 & -78.1 & & & 254.6 & -41.0 & 135 & 6.0 \\
\hline M9217 & $6 / 6$ & $269 / 16$ & 276.5 & -25.7 & & & 278.1 & -41.5 & 11 & 21.2 \\
\hline M9223 & $6 / 4$ & $54 / 38$ & 219.1 & -59.7 & & & 226.0 & -22.4 & 19 & 21.8 \\
\hline N3871 & $6 / 6$ & $9 / 22$ & 234.6 & -67.2 & & & 213.9 & -48.9 & 24 & 13.9 \\
\hline N3883 & $6 / 6$ & $269 / 16$ & 143.9 & -47.1 & & & 132.9 & -36.6 & 32 & 11.9 \\
\hline D7 & $7 / 6$ & $85 / 20$ & 278.0 & -79.9 & & & 269.5 & -60.1 & 44 & 10.2 \\
\hline D8 & $7 / 3$ & $85 / 20$ & 269.6 & -67.6 & & & 267.6 & -47.6 & 47 & 18.1 \\
\hline D9 & $7 / 6$ & $85 / 20$ & 235.6 & -66.2 & & & 247.9 & -47.7 & 22 & 14.8 \\
\hline D10 & $6 / 6$ & $85 / 20$ & 232.2 & -73.8 & & & 249.6 & -55.3 & 15 & 17.8 \\
\hline D11 & $7 / 6$ & $85 / 20$ & 262.7 & -72.4 & & & 263.9 & -52.4 & 16 & 17.2 \\
\hline M9205-GC & $6 / 4$ & $62 / 41$ & 107.8 & -20.5 & & & 130.5 & -43.8 & & 7.1 \\
\hline M9211-GC & $6 / 4$ & $62 / 41$ & $99.2-$ & 14.5 & & & 116.5 & -44.1 & & 29.2 \\
\hline N3865-GC & $6 / 4$ & 9/22 & 230.9 & -49.3 & & & 219.7 & -31.4 & & 8.7 \\
\hline N3871-GC & $6 / 3$ & $9 / 22$ & 96.5 & -17.8 & & & 103.5 & -17.5 & & 25.9 \\
\hline N3877 & $6 / 6$ & $9 / 22$ & 163.6 & 25.3 & & & 171.6 & 28.5 & 33 & 12.7 \\
\hline D7 & $7 / 4$ & $85 / 20$ & 0.7 & -43.8 & & & 341.0 & -44.4 & 12 & 27.1 \\
\hline D8 & $7 / 6$ & $85 / 20$ & 6.0 & -53.1 & & & 338.3 & -54.3 & 53 & 9.9 \\
\hline D9 & $7 / 7$ & $85 / 20$ & 18.1 & -40.5 & & & 359.7 & -47.4 & 63 & 7.9 \\
\hline D11 & $7 / 5$ & $85 / 20$ & 26.2 & -38.3 & & & 9.5 & -48.1 & 217 & 5.4 \\
\hline Mean & $(18 / 10)$ & & 183.9 & 38.4 & 34 & 8.5 & 167.0 & 44.3 & 41 & 7.8 \\
\hline
\end{tabular}

П р и м е ч а н и е. \# - два сайта с аномальными направлениями, не включенными в расчет среднего значения компоненты А. Курсивом показаны результаты, где вместо склонения и наклонения среднего направления даны координаты нормали к средним по сайтам кругам перемагничивания и ошибка ее определения. Остальные пояснения как к табл. 1.

$\mathrm{N}$ o t e. \# - two anomalous sites excluded from computation of the component A overall mean. The entries in italics denote the directions of normals to site-mean remagnetization circles and their confidence circles. Other notation as in Table 1.

вполне ясен. Поскольку вторичная намагниченность везде имеет обратную полярность, можно предположить, что перемагничивание произошло во время суперхрона обратной полярности Киама (верхний карбон - бо́льшая часть перми, около 315-265 млн лет). С другой стороны, среднее наклонение вторичной намагниченности $-70.5^{\circ} \pm 4.2^{\circ}$ примерно на $20^{\circ}$ круче, чем наклонение в верхнепермских базальтах объектов РА и PB $\left(-49^{\circ} \pm 4^{\circ}\right)$ (табл. 3). Видимо, вторичная намагниченность должна существенно отличаться по возрасту от намагниченности верхнепермских базальтов.

Послепермские интрузии известны в разных частях Казахстана [Бекжанов и др., 2000]. Примерно в 200 км к северу от нашего района работ расположены интрузии семейтаусского комплекса, возраст которых составляет $248.2 \pm 0.5$ млн лет $\left({ }^{40} \mathrm{Ar} /{ }^{39} \mathrm{Ar}\right.$ метод по санидину) [Lyons et al., 2002]. Палеомагнитный полюс (широта $\Phi=56^{\circ}$ с.ш., долгота $\Lambda=139^{\circ}$ в.д., радиус круга доверия А95 $=8^{\circ}$ ) для этого комплекса [Lyons et al., 2002] неотличим от среднего полюса $\left(\Phi=50^{\circ}\right.$ с.ш., $\Lambda=134^{\circ}$ в.д., А95 $=4^{\circ}$ ) для вторичной компоненты района Чингиза, а также близок к полюсу для Сибирских траппов (табл. 4). Возникает некоторое противоречие: семейтаусский полюс заметно моложе окончания суперхрона Киама ( 265 млн лет [Opdyke, Channel, 1996]), и если перемагничивание одновозрастно с семейтаусским комплексом, не вполне понятно, почему вторичная намагниченность в районе Чингиза всюду имеет обратную полярность - ведь в триасе смены полярности геомагнитного поля происходили достаточно часто [Opdyke, Channel, 1996].

Несмотря на некоторую неясность с возрастом перемагничивания, из совпадения направлений вторичной намагниченности во всех изученных разрезах района можно сделать вывод - после перемагничивания район не подвергался заметным деформациям; в частности, здесь не было блоковых вращений, характерных для присдвиговых деформаций. 
Т а б л и ц а 3. Сводные палеомагнитные результаты по палеозойским породам северо-востока Казахстана

$\mathrm{T}$ a b l e 3. Summary of the Paleozoic paleomagnetic data from NE Kazakhstan

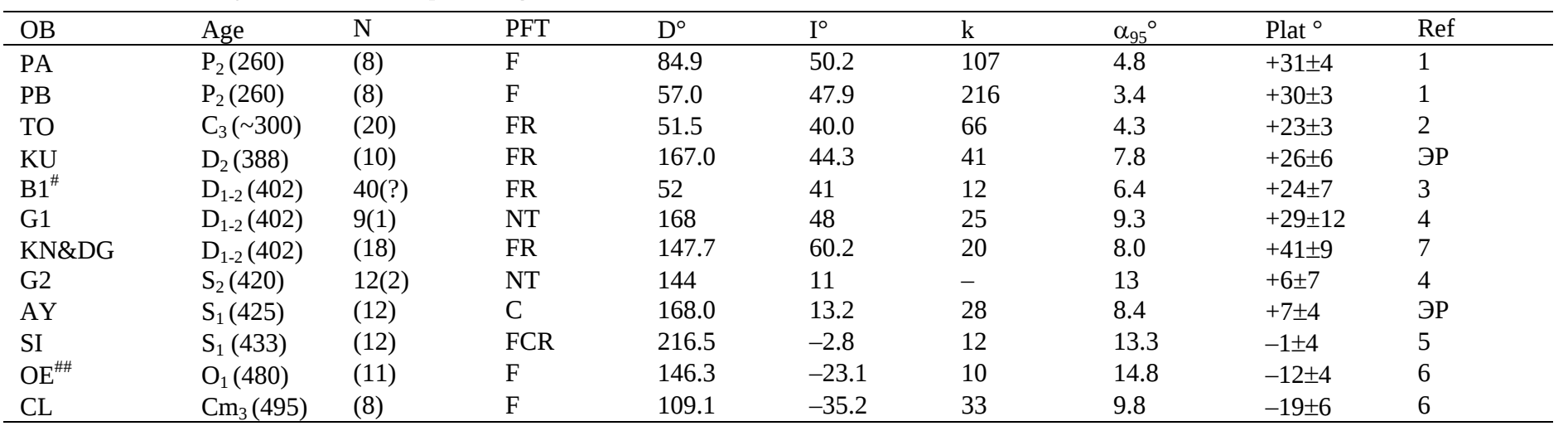

П р и м е ч а н и е. \# - исключен из рассмотрения (подробности в тексте); \#\# - вытянутое распределение средних направлений по сайтам

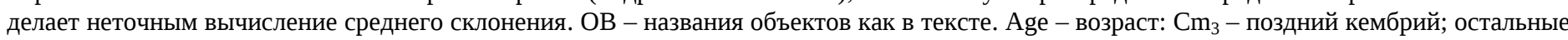
обозначения стандартные; возраст в миллионах лет дан по [A geologic time scale..., 2004]; N - число образцов (сайтов), использованных для вычислений; PFT - положительные полевые тесты: F - складки, R - обращения, C - конгломератов, NT - нет тестов; Plat - палеоширота. Все палеомагнитные результаты приведены как направления прямой полярности в древней системе координат. Ref - ссылки: 1 [Levashova et al., 2003b]; 2 - [Abrajevitch et al., 2008]; 3 - [Буртман и др., 1998]; 4 - [Гришин и др., 1997]; 5 - [Levashova et al., 2003a]; 6 [Collins et al., 2003]; 7 - [Levashova et al., 2009]; ЭР - эта работа. Остальные пояснения как к табл. 1.

$\mathrm{N}$ o t e. \# - excluded from analysis (see text for detail). \#\# - banana-type distribution of the site-means renders the object-mean declination imprecise. $\mathrm{OB}$ - objects labeled as in the text. Age: $\mathrm{Cm}_{3}$ - Late Cambrian; the other notation is standard; ages in Ma are after [A geologic time scale..., 2004]. N, the number of samples (sites) used; PFT - positive field tests: F - fold, R - reversal, C - conglomerate, NT - no tests. Plat - paleolatitude. All paleomagnetic data are presented as normal polarity directions in stratigraphic coordinates. Ref - references: 1 - [Levashova et al., $2003 b]$; 2 [Abrajevitch et al., 2008]; 3 - [Буртман и др., 1998]; 4 - [Гришин и др., 1997]; 5 - [Levashova et al., 2003a]; 6 - [Collins et al., 2003]; 7 - [Levashova et al., 2009]; TP, this paper. Other notation as in Table 1.

\section{5. ИНТЕРПРЕТАЦИЯ И ДИСКУССИЯ}

\section{1. ВЫБОР ПОЛЯРНОСТИ НАМАГНИЧЕННОСТИ}

Для района Чингизской палеодуги была получена последовательность палеомагнитных определений с возрастом от позднего кембрия до поздней перми (см. табл. 3). Обратная полярность позднепермского результата однозначна, и можно совершенно уверенно утверждать, что в поздней перми район исследований находился в средних широтах северного полушария. Палеомагнитные определения по каменноугольным комплексам Чингизской палеодуги получить не удалось, но есть данные по верхнекаменноугольным породам Балхаш-Илийского вулканического пояса (ТО в табл. 3) [Abrajevitch et al., 2008]. Здесь выделена намагниченность прямой полярности с северо-восточными склонениями, так же однозначно указывающая на расположение региона в субтропических широтах северного полушария. Если считать, что направления с положительными наклонениями в верхне- и среднедевонских породах имеют прямую полярность, то по наклонению они более или менее совпадают с позднепалеозойскими, но повернуты относительно них примерно на $100^{\circ}$ по часовой стрелке (см. табл. 3). В позднем и среднем девоне, как и в позднем палеозое, район исследований должен был находиться в средних широтах северного полушария, но в верхнем девоне - нижнем карбоне имел место разворот всего региона примерно на $100^{\circ}$ по часовой стрелке. Другой выбор полярности заставляет предполагать, что в позднем девоне - раннем карбоне (т.е. за 45 млн лет) район переместился на $60^{\circ}$ только по широте, а такая скорость движений не кажется правдоподобной.

Силурийские результаты по склонению не отличаются от девонских, за исключением результата SI (см. табл. 3), где, по всей видимости, произошел дополнительный поворот в результате присдвиговых деформаций вдоль разломов, ограничивающих структуры Чингиза с юго-востока [Levashova et al., 2003]. Все силурийские наклонения значительно положе, чем девонские (см. табл. 3); следовательно, в силуре Чингизская палеодуга должна была находиться в северных приэкваториальных широтах. Если в силуре район находился в приэкваториальных широтах северного полушария, значит, в позднем силуре - раннем девоне он постепенно смещался на север, без существенных поворотов. Выбор противоположной полярности для силурийских данных заставляет предполагать, что район, двигаясь на север, еще и повернулся на $180^{\circ}$ за время меньше 10 млн лет, что выглядит достаточно неправдоподобно.

Выбор полярности для раннепалеозойских данных (см. табл. 3) не столь однозначен. Если предположить, что кембрийские и ордовикские направления - это направления прямой полярности, то в раннем палеозое 
Чингизская палеодуга находилась в южном полушарии и в течение всего палеозоя постепенно смещалась на север, что согласуется с кинематикой Балтии и Сибири. Если же раннепалеозойские направления имеют обратную полярность, то в кембрии - начале ордовика Чингизская палеодуга должна была находиться в северном полушарии и двигаться на юг, а где-то во второй половине ордовика она развернулась на $180^{\circ}$ и с силура уже двигалась на север. Такой разворот всей структуры и изменение направления ее движения на противоположное требует большого количества дополнительных предположений и допущений и никак не подкрепляется геологическими данными. Таким образом, хотя второй сценарий кинематики Чингизской палеодуги нельзя исключить из рассмотрения полностью, первый все же кажется гораздо более правдоподобным.

\section{2. АНАЛИЗ СКЛОНЕНИЙ И ПОВОРОТОВ}

Казахский и Балхаш-Илийский вулканические пояса (см. рис. 2) имеют сильно изогнутую, подковообразную форму, и во всем интервале от позднего силура до ранней перми вулканизм здесь имел надсубдукционную природу [Курчавов, 1994; Тевелев, 2001]. Подковообразная форма этих вулканических поясов привлекала внимание многих геологов. Некоторые авторы считали эту форму первичной (например [Зайцев, 1984; Курчавов, 2001]), другие связывали ее с разного рода деформациями - ороклинальным изгибанием или крупномасштабными смещениями по сдвигам (например [Zonenshain et al., 1990; Şengör, Natal'in, 1996; Teвелев, 2001]).

Первая попытка проверить гипотезу о вторичном изгибании вулканических поясов с помощью палеомагнитных данных была предпринята Д.В. Гришиным с соавторами [1997]. Они представили данные по нескольким силурийским и девонским разрезам Казахского пояса и пришли к выводу, что северная и южная ветви Казахского пояса в результате ороклинального изгибания повернулись друг относительно друга примерно на 90. K сожалению, эти выводы основаны на палеомагнитных данных, полученных по крайне маленьким коллекциям, и слабо подтверждены полевыми тестами.

Позднее были получены новые палеомагнитные данные по раннеордовикским и раннесилурийским комплексам Чингизской палеодуги [Colins et al., 2003; Levashova et al., 2003a], которые сравнили с данными по позднему ордовику Северного Тянь-Шаня [Bazhenov et al., 2003]. Был сделан вывод о том, что южная ветвь вулканических поясов имеет сейчас простирание, близкое к изначальному, тогда как северная ветвь после среднего девона повернулась приблизительно на $180^{\circ}$. Этот вывод базировался на данных по структурам, перекрытым комплексами вулканических поясов, а не по породам самих поясов, а потому являлся сугу- бо предварительным.

Новые палеомагнитные данные по южной ветви Казахского и Балхаш-Илийского вулканических поясов позволили проанализировать проблему заново [Van der Voo et al., 2006]. Было установлено, что в поздней перми - раннем мезозое в южной ветви происходили вращения относительно мелких блоков против часовой стрелки на угол 50-90. Эти вращения вызваны тем, что изученные районы попадают в область распределенных сдвигов, захватывающую большую часть Тянь-Шаня и прилегающие регионы [Bazhenov et al., 1999]. Ранее, в период между средним девоном и поздней пермью, северная ветвь вулканических поясов развернулась примерно на $180^{\circ}$ относительно южной в результате ороклинального изгибания всей системы.

Однако последний вывод оставался слабообоснованным из-за малого числа среднепалеозойских палеомагнитных данных из южной и средней ветвей петли. Новые результаты по девону южной ветви были получены в работе [Abrajevitch et al., 2007], и там же проведен анализ всех данных по силурийским, девонским и пермским породам вулканических поясов. Так как в поздней перми - раннем мезозое в южной ветви петли произошли повороты относительно мелких блоков против часовой стрелки на угол 50-90 [Van der Voo et al., 2006], в силурийские и девонские результаты из этой части петли были внесены поправки за позднепермские вращения. Эта процедура позволила оценить повороты, происходившие в допозднепермское время. Исправленные склонения в южной ветви вулканических поясов в целом смотрят на север, а склонения в силурийских и девонских породах северной ветви - на юг (рис. 7). Из полученного распределения склонений достаточно очевидно, что первоначально Казахский вулканический пояс имел почти прямолинейные очертания.

В нашей работе представлены новые данные по силурийским и девонским комплексам района Чингизской палеодуги, то есть по северной ветви вулканических поясов. Было показано, что по всему району исследований направления перемагничивания совпадают между собой, а также согласуются с пермско-триасовыми эталонными направлениями для Сибири. Очевидно, в этом районе не происходило сколько-нибудь значительных послепермских поворотов. Следовательно, склонения, полученные по силурийским и девонским породам Чингиза, отражают допознепермские деформации. Все полученные направления ориентированы на юг (табл. 3), что подтверждает построения [Abrajevitch et al., 2007].

\section{3. АНАЛИЗ НАКЛОНЕНИЙ И ПАЛЕОШИРОТ}

Для Чингизской палеодуги была получена последовательность из девяти палеомагнитных определений для интервала времени с позднего кембрия по позднюю пермь (см. табл. 3). Это дает возможность срав- 


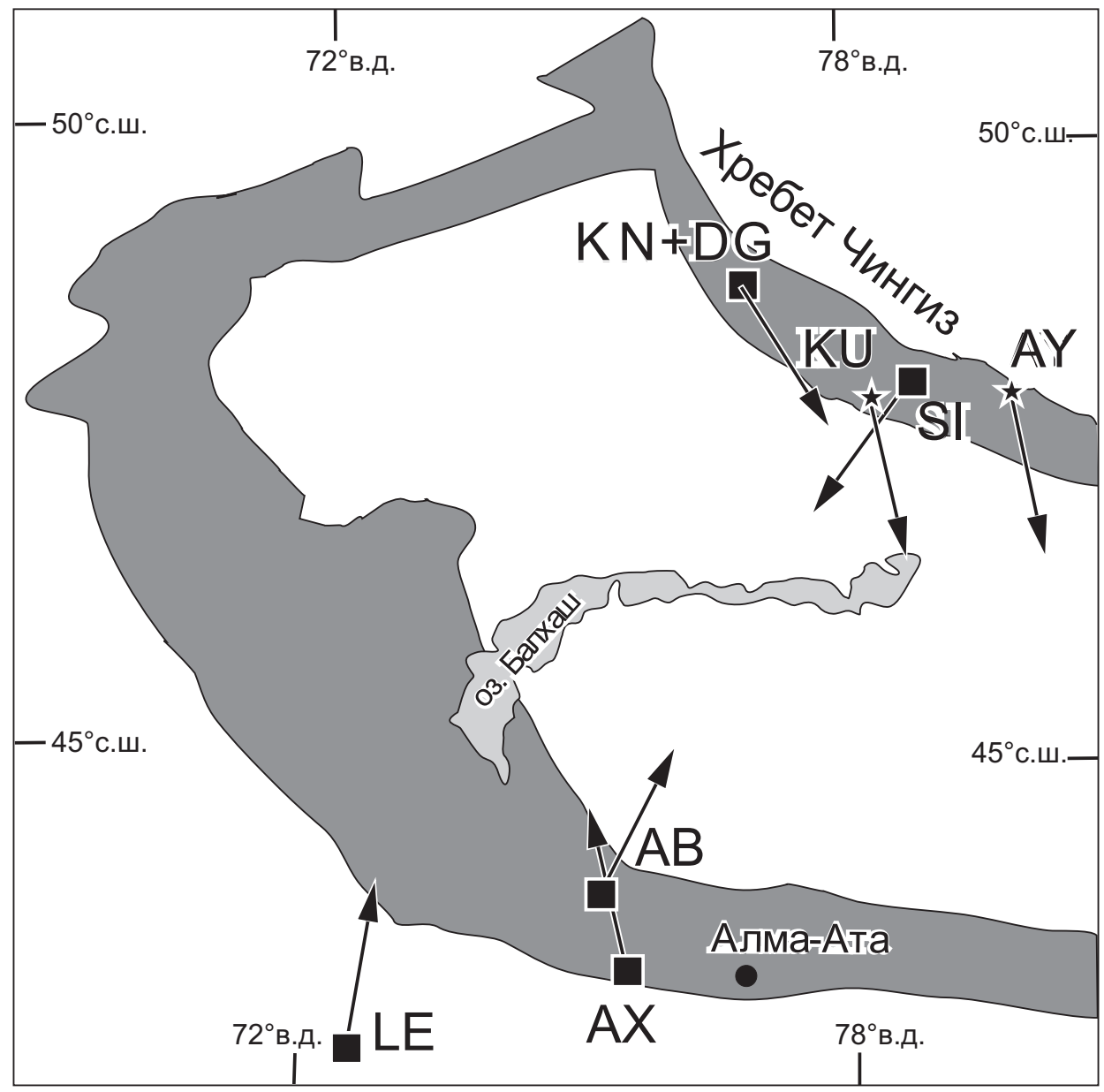

Рис. 7. Схема Девонской вулканической петли (серое; упрощенный рис. 2). Стрелками обозначены направления первичной намагниченности в силурийских и девонских породах Казахского вулканического пояса. Показаны только результаты, полученные при полном размагничивании коллекций, с применением компонентного анализа, и подтвержденные полевыми тестами. Звездочки - результаты из этой работы, обозначенные так же, как в тексте. Квадратики - результаты из других работ: KN+DG [Levashova et al., 2009]; SI [Levashova et al. 2003a]; AX [Alexyutin et al., 2005]; AB [Abrajevitch et al., 2007]; LE [Levashova et al., 2007]. Последние два результата скорректированы за послепермские повороты, как предложено в работе [Abrajevitch et al., 2007].

Fig. 7. Schematic outline of the Devonian volcanic belt (gray; simplified from Figure 2) with the Silurian and Devonian paleomagnetic declinations (arrows). Only the results are shown that are based on full demagnetization and confirmed by positive field tests. Stars show the results from this study labeled as in the text. Squares - published data are from: KN+DG [Levashova et al., 2009]; SI [Levashova et al., 2003a]; AX [Alexyutin et al., 2005]; AB [Abrajevitch et al., 2007]; LE [Levashova et al., 2007]. The last two results are corrected for the Late Paleozoic rotations as described in [Abrajevitch et al., 2007].

нивать движения Чингизской палеодуги и обрамляющих Урало-Монгольский пояс Таримской, Сибирской и Восточно-Европейской платформ путем пересчета кривых кажущейся миграции полюса (ККМП) этих платформ в последовательности эталонных палеоширот и склонений для района исследований $\left(48.5{ }^{\circ} \mathrm{C} . ш\right.$. , $78.5^{\circ}$ в.д.). Такой пересчет показывает, на какой широте находилась бы Чингизская дуга в каждый момент времени, если бы она всегда была неподвижна относительно той или иной платформы. Сравнение ожидаемых палеоширот и наблюденных значений (см. табл. 3) позволяет оценить масштаб перемещений этой дуги относительно каждой платформы.

K сожалению, по Тариму на сегодняшний день слишком мало палеомагнитных данных, и, на наш взгляд, построить сколь-нибудь обоснованную ККМП нельзя. Для Балтии зависимости эталонных палеоширот от времени, полученные разными авторами [Van der Voo, 1993; Smethurst et al., 1998a], в целом согласуются (рис. $8, a$ ). Различия же частично определяются использованием разных математических методов при построении кривых, а частично - селекцией результатов, качество которых по-разному оценивалось разными исследователями. При имеющемся количестве палеомагнитных полюсов по Балтии нельзя отдать явного предпочтения ни одной из кривых. Для среднего позднего палеозоя наблюденные палеошироты хорошо согласуются с ожидаемыми, пересчитанными из 


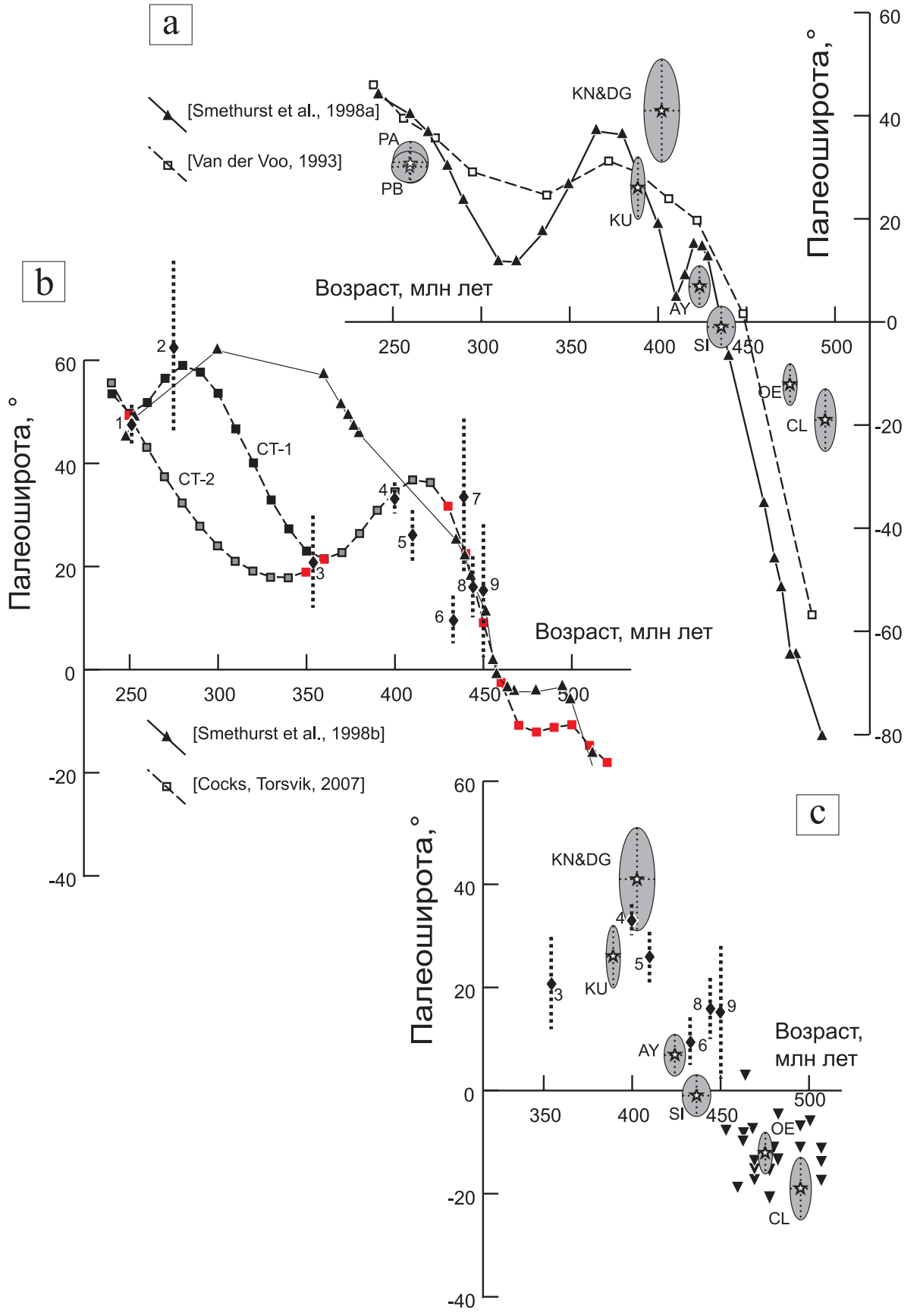

Рис. 8. Сравнение эталонных палеоширот, полученных пересчетом палеомагнитных полюсов разных кратонов для района исследований $\left(48.5^{\circ} \mathrm{N}, 78.5^{\circ} \mathrm{E}\right)$, и наблюденных палеоширот района Чингизской дуги (см. табл. 3) в зависимости от времени: $a-$ эталонные значения получены пересчетом двух вариантов кривой миграции полюса Балтии. Звездочками с овалами доверия показаны наблюденные палеошироты для Чингизской дуги, обозначенные как в тексте и в табл. $3 ; b$ - сравнение эталонных палеоширот, полученных пересчетом разных кривых миграции полюса Сибири. Красными (серыми) значками на кривой СТ2 обозначены обоснованные данными (интерполированные) интервалы. Для силурийско-пермского времени также показаны палеошироты для отдельных палеомагнитных результатов (ромбики) с доверительными интервалами (вертикальные пунктирные линии); нумерация результатов дана в табл. 4; $c$ - сравнение наблюденных палеоширот (рис. 8, a) с эталонными значениями, полученными пересчетом единичных палеомагнитных полюсов Сибири (табл. 4); раннепалеозойские данные показаны треугольниками (для наглядности, без интервалов доверия), а более молодые данные - ромбиками с доверительными интервалами (вертикальные пунктирные линии).

Fig. 8. Plots of paleolatitude versus age for the observed paleolatitudes for the Chingiz area (Table 3) and the reference values; the latter are recalculated from paleomagnetic poles for different cratons to a common point at $48.5^{\circ} \mathrm{N}, 78.5^{\circ} \mathrm{E}$ : $a$ - comparison of the observed data and the reference paleolatitudes extrapolated from two APWP's for Baltica. The observed data are plotted as stars with shaded $95 \%$ confidence limits with labels as in the text and Table 3; $b$ - comparison of the paleolatitudes extrapolated from different versions of the Siberian APWP. Red (gray) symbols on the CT2 plot denote the data-based (interpolated) intervals. For the Silurian-Permian time, unit values with confidence limits are also shown as diamonds with error bars (thick dashed lines) and labeled as in Table 4; $c$ - comparison of the observed paleolatitudes (Fig. 8, $a$ ) with the reference values recalculated from the Siberian unit poles (Table 4); triangles are for the Early Paleozoic data (for clarity, without error bars); the younger data are shown as diamonds with error bars (thick dashed lines). 
ККМП Балтии, но низкие раннепалеозойские палеошироты Чингизской палеодуги резко отличаются от ожидаемых высоких южных палеоширот. Можно говорить о том, что в позднем кембрии - ордовике палеодуга располагалась заметно севернее Балтии и двигалась на север гораздо медленнее, чем платформа. Начиная с силура движение Чингизской палеодуги было более или менее согласовано с движением Балтии.

ККМП Сибири определена значительно хуже. Все версии кривой, опубликованные до 2007 г., для среднего и верхнего палеозоя основаны на устаревших данных, полученных при неполном размагничивании образцов и без компонентного анализа. Когда Л. Кокс и Т. Торсвик [Cocks, Torsvik, 2007] рассчитывали новую версию ККМП Сибири, они исключили все эти данные из рассмотрения.

Появление нового полюса по раннепермским дайкам [Pisarevsky et al., 2006] не только не улучшило ситуацию, но даже создало новые проблемы. Это первый результат, полученный по хорошо датированным породам при полном размагничивании образцов и с применением компонентного анализа. Однако этот полюс помещает Сибирскую платформу далеко на север, в положение, несовместимое с любыми представлениями о формировании Евразии [Cocks, Torsvik, 2007]. Аномальность раннепермского полюса может объясняться несколькими причинами. Во-первых, авторы смогли изучить только пять даек, что заведомо недостаточно для осреднения вековых вариаций магнитного поля. Более того, дайки были отобраны в Байкальской рифтовой зоне и вполне могут быть наклонены, а в этом случае направления их намагниченности не соответствуют никакому древнему магнитному полю. Есть только одна возможность оценить достоверность спорного полюса - получить новые данные по одновозрастным породам. Пока же Л. Кокс и Т. Торсвик [Cocks, Torsvik, 2007] были вынуждены дать два варианта ККМП Сибири - включающий полюс [Pisarevsky et al., 2006] и не включающий его (СТ1 и СТ2, рис. 8, b). Нам вариант СТ2, рассчитанный без учета раннепермского полюса, кажется предпочтительнее. В итоге новая кривая [Cocks, Torsvik, 2007] включает достаточно многочисленные и достаточно надежные данные по раннему палеозою, один единственный полюс для границы девона и карбона [Kravchinsky et al., 2002] и пермско-триасовые полюса по сибирским траппам (табл. 4).

Итак, кривая [Cocks, Torsvik, 2007] для послеордовикского времени базируется на крайне малом числе результатов (рис. $8, b$ ). В такой ситуации использование сплайн-функций для расчета ККМП может создавать искусственные экстремумы на тех участках кривой, где данных мало или нет вообще. Чтобы избежать этой проблемы, мы решили сравнивать казахстанские данные не только с кривой СТ2 [Cocks, Torsvik, 2007], но и с единичными полюсами по Сибирской платфор- ме, пересчитанными в палеошироты. Использованные полюса приведены в табл. 4 и показаны на рис. 8, c.

Уже после опубликования кривой [Cocks, Torsvik, 2007] появились новые результаты по нижнесилурийским отложениям [Шацилло, Паверман, 2006], в которых выделены среднетемпературная вторичная (\#5, табл. 4) и высокотемпературная, предположительно первичная, компоненты намагниченности (\#6, табл. 4). Возраст вторичной намагниченности авторы оценивают как позднесилурийский - раннедевонский. Интересно, что новый раннесилурийский полюс очень сильно отличается от ранее опубликованного [Torsvik et al., 1995] одновозрастного полюса (\#7, табл. 4). Учитывая, что полюс \#7 получен всего по девяти образцам, мы предпочли исключить его из рассмотрения.

Не имея достаточного количества полюсов для Сибирской платформы, мы попытались привлечь дополнительные источники информации. По верхнесилурийским - нижнедевонским красноцветам Тувы был опубликован достаточно надежный результат [Bachtadse et al., 2000]. Хотя Тува и является частью Урало-Монгольского подвижного пояса, она, согласно существующим геологическим представлениям, причленилась к Сибирской платформе не позднее ордовика [Моссаковский и др., 1993; Dobretsov et al., 1995]. Присдвиговые блоковые вращения были возможны в Туве и в послеордовикское время, и работа [Bachtadse et al., 2000] это подтверждает, но существенных перемещений Тувы относительно Сибири уже не было. Мы сочли возможным использовать результат [Bachtadse et al., 2000] для приблизительного расчета ожидаемой палеошироты Чингизской палеодуги в конце силура начале девона.

Описанный массив ожидаемых палеоширот мы сравнили с наблюденными данными для Чингизской палеодуги (рис. 8, в). Наблюденные кембрийские, ордовикские и силурийские палеошироты совпадают с одновозрастными ожидаемыми значениями. Палеоширота, пересчитанная из позднесилурийского - раннедевонского результата по Туве [Bachtadse et al., 2000], так же неплохо согласуется с представленным в этой работе результатом по живетским базальтам (KU). Однако для всего интервала с начала девона до конца перми по Сибири есть только один позднедевонскийраннекарбоновый полюс [Kravchinsky et al., 2002] и для этого интервала времени сравнение движений Сибири и других блоков остается крайне спекулятивным.

Тем не менее совпадение ожидаемых сибирских палеоширот с палеоширотами, наблюденными в районе Чингизской островной дуги, вряд ли можно счесть случайным. С достаточно большой степенью уверенности можно предположить, что, по крайней мере с позднего кембрия по ранний девон, движение Чингизской палеодуги было согласовано с движением Сибирской платформы. В поздней перми их палеошироты снова совпадают. Были ли перемещения этих двух блоков взаимосвязаны в девоне - перми, в настоящее 
Т а б л и ц а 4. Палеозойские палеомагнитные полюса для Сибири

$\mathrm{T}$ a b l e 4. The Paleozoic paleomagnetic poles for Siberia

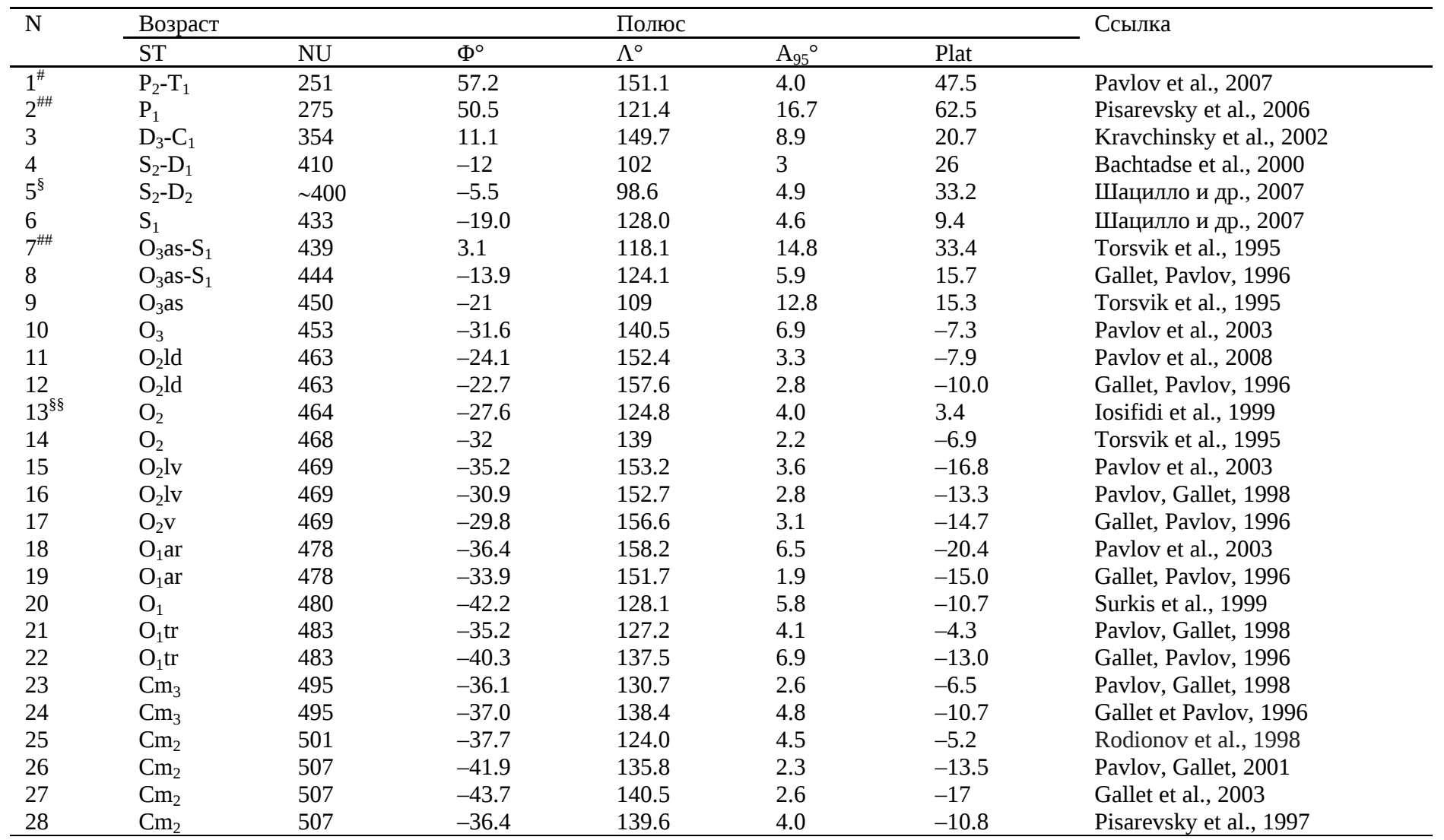

П р и м е ч а н и е. \# - средний полюс по Сибирским траппам (полюс NSP4 из [Pavlov et al., 2007]); \#\# - исключен из анализа (подробности в тексте); § - полюс перемагничивания, возраст которого определен как позднесилурийский - раннедевонский [Шацилло и др., 2007]; $\S \S$ - по направлениям прямой и обратной полярности, полученным [Iosifidi et al., 1999] по среднеордовикским породам, мы рассчитали единый полюс, а Л. Кокс и Т. Торсвик [Cocks, Torsvik, 2007] рассчитали полюса прямой и обратной полярности по отдельности; ST - стратиграфический возраст пород (компонент) дан так же, как у авторов соответствующих работ. Обозначения: $\mathrm{Cm}_{2}-$ средний кембрий; Сm $_{3}-$ поздний кембрий; ярусы: $\mathrm{tr}$ - тремадокский, ar - аренигский, lv - лланвирнский, ld - лландейлский, as - ашгилский. NU - абсолютный возраст дан по [A geologic time scale, 2004]. Ф - широта и $\Lambda$ - долгота северного полюса; $\mathrm{A}_{95}$ - радиус круга доверия. Рlat, палеоширота точки с координатами $48.5^{\circ}$ с.ш., $78.5^{\circ}$ в.д., в которую пересчитывались все полюса.

N o t e. \# - Mean pole for Siberian traps (pole NSP4 from [Pavlov et al., 2007]). \#\# Excluded from analysis (see text for detail); $§-$ The overprint pole of the Late Silurian-Early Devonian age [Шацилло и др., 2007]; §§ - We combined normal and reverse data on the Ordovician rocks from [Iosifidi et al., 1999], while two poles for each polarity separately were computed by [Cocks, Torsvik, 2007]; ST - stratigraphic age of rocks (components) is as in the cited paper. Ages: $\mathrm{Cm}_{2}$ - Middle Cambrian; $\mathrm{Cm}_{3}$ - Late Cambrian; stages: $\mathrm{tr}$ - Tremadocian, ar - Arenigian, lv - Llanvirnian, ld - Llandeilian, as - Ashgilian. NU - age in Ma after [A geologic time scale, 2004]. $\Phi$ - latitude, and $\Lambda$ - longitude of the northern pole. $A_{95}$ - radius of confidence circle. Plat, paleolatitude of the common point at $48.5^{\circ} \mathrm{N}, 78.5^{\circ} \mathrm{E}$, which all poles were recalculated to.

время по палеомагнитным данным установить невозможно.

\section{4. СРАВНЕНИЕ ПОЛУЧЕННЫХ ДАННЫХ С СУЩЕСТВУЮЩИМИ ПАЛЕОГЕОГРАФИЧЕСКИМИ РЕКОНСТРУКЦИЯМИ}

Чингизская палеодуга расположена более чем в тысяче километров от Сибирской платформы. Их разделяет целый ряд орогенных систем разного возраста позднепалеозойская Иртыш-Зайсанская зона, каледониды Алтая, Кузнецкого Алатау, Саян и Тувы. Неудивительно, что в большинстве опубликованных палеогеографических реконструкций никакой связи между
Чингизской палеодугой и Сибирской платформой не предполагается, по крайней мере в раннем палеозое.

В моделях [Моссаковский и др., 1993; Диденко и др., 1994; Куренков и др., 2002] многочисленные микроконтиненты, изолированные друг от друга океаническими и задуговыми бассейнами и островными дугами, в силуре причленяются к Сибирской платформе, образуя композитный Сибирско-Казахстанский континент. В моделях [Kheraskova et al., 2003; Filippova et al., 2001] в силуре большая часть этих блоков сталкиваются, образуя Казахстанский континент, который затем двигается независимо от других плит. Согласно [Моссаковский и др., 1993; Диденко и др., 1994; Курен- 


\section{Реконструкции на середину силура ( 425 млн лет)}

Согласно [Şengör, Natal'in, 1996]

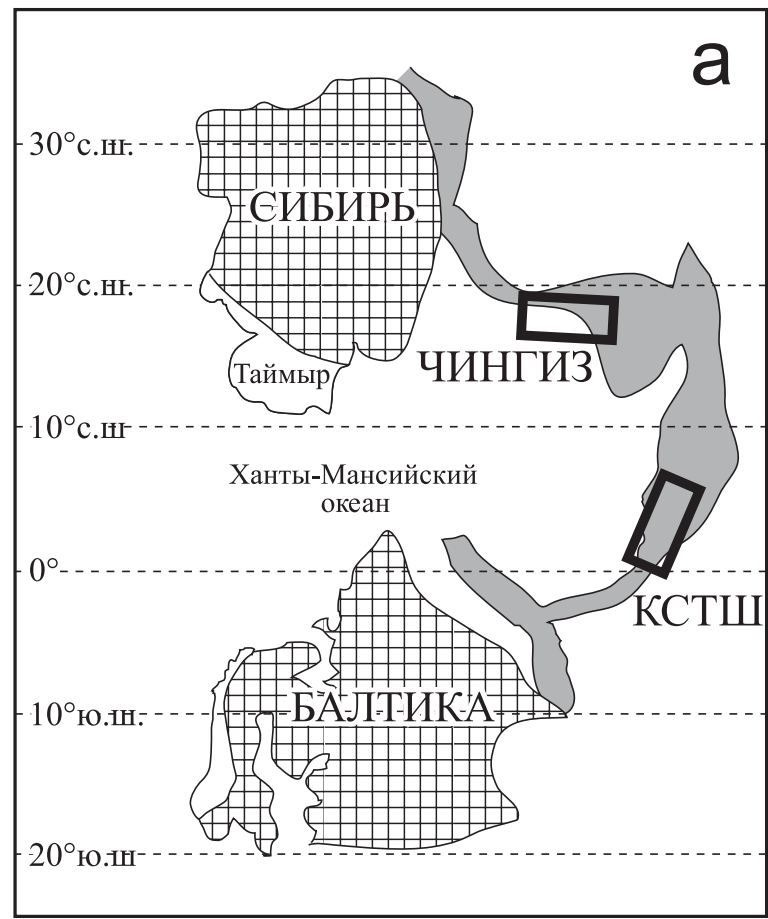

Согласно [Levashova et al., 2009]

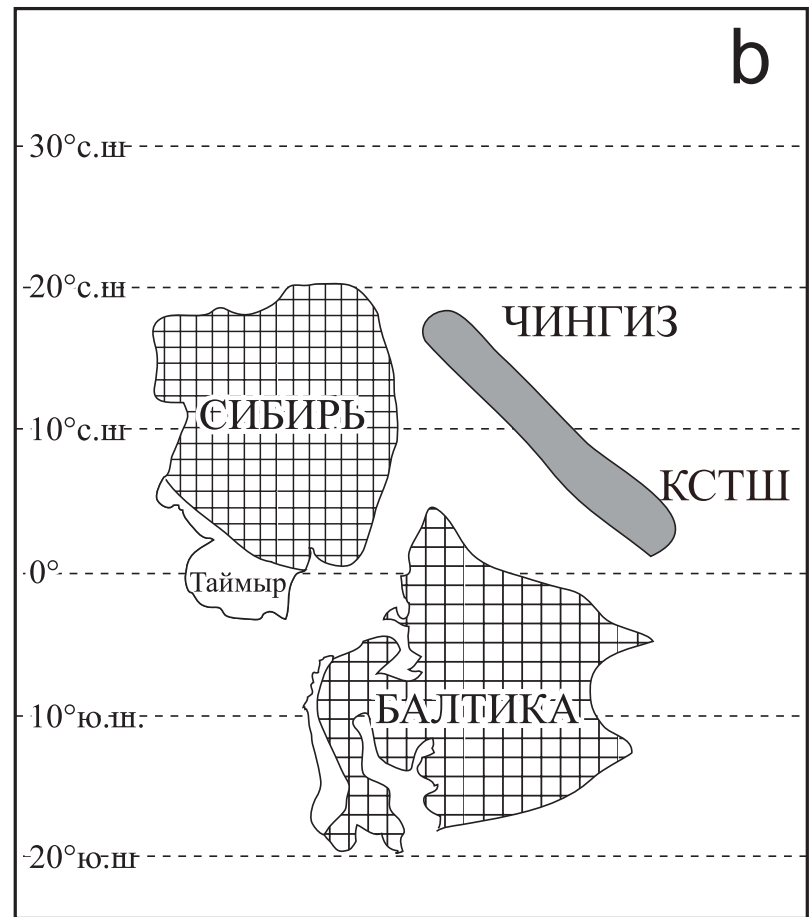

Эта работа

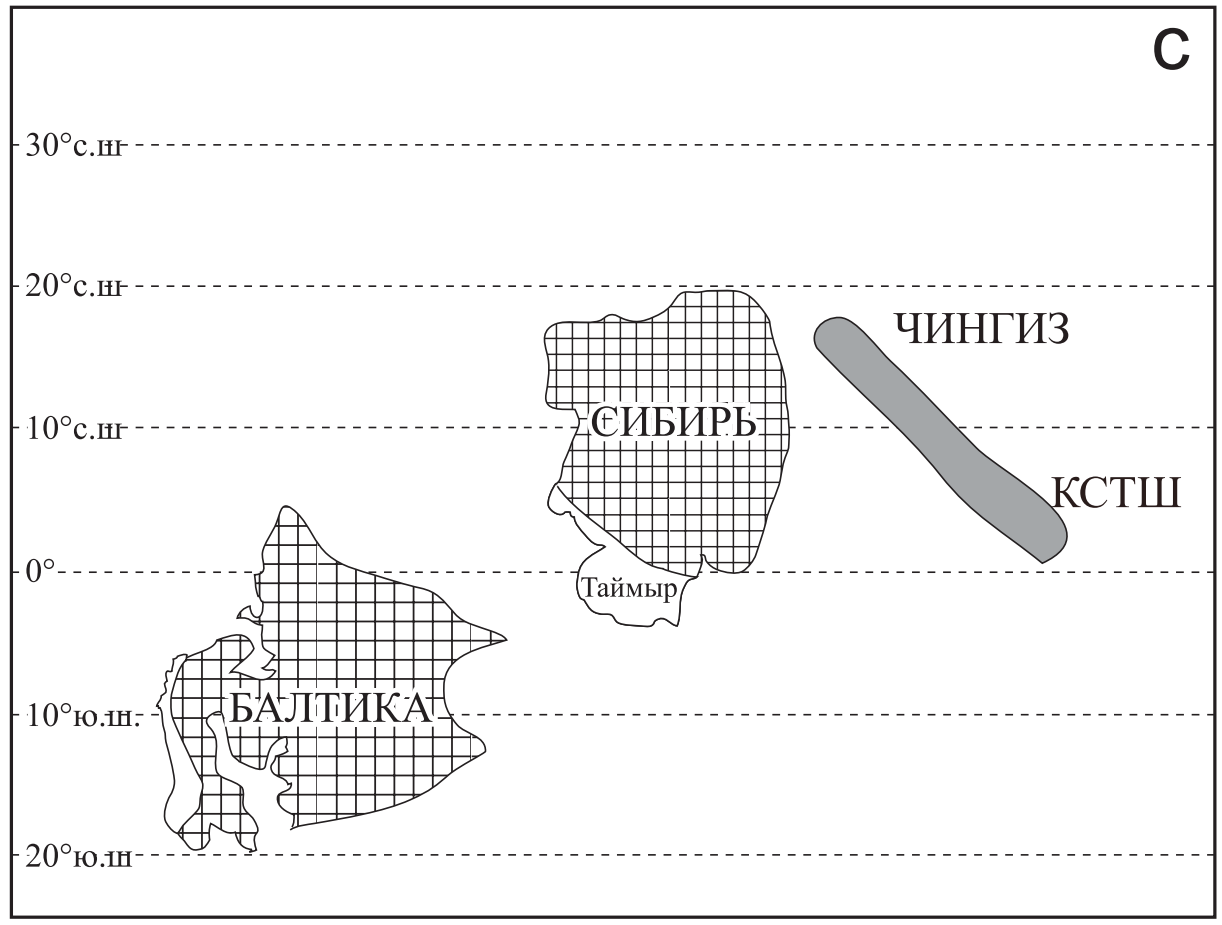

Рис. 9. Сравнение взаимного положения Балтии, Сибири, КСТШ и Чингизской палеодуги в середине силура: $a$ - упрощенная реконструкция по [Şengör, Natal'in, 1996]; b - как предложено в [Levashova et al., 2009], Сибирь показана в соответствии с новым полюсом [Шацилло и $\partial p ., 2007]$ к западу от Балтии; $c$ - альтернативная реконструкция с Сибирью к востоку от Балтии. Все структуры расположены так, как они могли находиться до ороклинального изгибания Казахстанского вулканического пояса (см. текст).

Fig. 9. Relationship between Baltica, Siberia, the KNTD and Chingiz paleoarc in the mid-Silurian time: $a$ - reconstruction simplified after [Şengör, Natal'in, 1996]; $b$ - as suggested in [Levashova et al., 2009], Siberia is located in accord with the new Silurian pole of [Шацилло u дp., 2007] to the west of Baltica; $c$ - a permissible alternative reconstruction with Siberia to the east of Baltica. All units are positioned, as they had to be before oroclinal bending of the Kazakh volcanic belt (see text for detail). 
ков и др., 2002] Чингизская дуга перемещается относительно Сибирской платформы в раннем палеозое, а согласно [Kheraskova et al., 2003; Filippova et al., 2001] относительные перемещения продолжаются до среднего карбона. Очевидно, что последовательность палеомагнитных определений, полученных в районе Чингизской палеодуги, плохо согласуется с этими моделями.

В модели [Şengör, Natal'in, 1996] предполагается, что в венде - раннем палеозое существовала огромная Кипчакская островная дуга, которая соединяла Балтию и Сибирь. Естественно, такая модель предполагает некоторую степень согласованности в движении платформ и различных частей Кипчакской дуги. Полученные по Кокчетав-Северо-Тяньшаньской области [Levashova et al., 2007] и по району Чингизской палеодуги (эта работа) последовательности палеомагнитных определений в целом согласуются с этой моделью.

Означает ли это, что данная модель верна? По нашему мнению, нет. Хотя мы и не собираемся детально обсуждать достоинства и недостатки этой модели, но хотим отметить, что для того, чтобы между Сибирью и Балтией мог существовать Ханты-Мансийский океан и Кипчакская дуга, с венда до конца девона Сибирь должна находиться примерно на 2000 км севернее Балтии (рис. 9, а). Однако согласно последним версиям ККМП Сибири и Балтии, это условие выполняется не всегда. Так, в кембрии - ордовике Балтия должна перемещаться на север с гораздо большей скоростью, чем Сибирь (как при этом может существовать Кипчакская дуга?), а в силуре Сибирь и Балтия в течение какого-то промежутка времени должны были находиться приблизительно на одной широте (рис. 9, $b, c$ ).

Таким образом, последовательности палеомагнитных определений по разным структурам Казахстана лишь отчасти соответствуют модели [Şengör, Natal'in, 1996], а для ряда интервалов времени просто ей противоречат. Пока что мы не можем предложить серию палеогеографических реконструкций, которые учитывали бы не только геологическую информацию, но и полученные за последние годы палеомагнитные данные. На сегодняшний день можно только сформулировать ряд условий, которые необходимо учитывать при создании таких реконструкций.

1. Широтные перемещения Кокчетав-СевероТяньшаньской области Урало-Монгольского пояса и Балтии должны быть схожими по крайней мере с верхнего ордовика до конца перми [Levashova et al., 2007].

2. Такое же подобие движений Чингизской островной дуги и Сибири имело место по крайней мере с позднего кембрия по ранний девон (эта работа).

3. Подковообразный Казахский вулканический пояс первоначально был почти прямолинейным и имел северо-западное простирание [Abrajevich et al., 2007].

4. Сибирь и Балтия должны располагаться в соответствии с современными версиями ККМП.

Выполнение условия 1 не обязательно означает принадлежность КСТШ и Балтии к одной плите, так же как выполнение условия 2 не обязательно означает принадлежность к одной плите Сибири и Чингизской дуги. Но для того, чтобы Чингизская дуга двигалась согласованно с Сибирью на протяжении примерно 100 млн лет, между ними не должно быть долгоживущих дивергентных и конвергентных границ, и, следовательно, дуга не должна была изменять свое расположение относительно платформы более чем на 5001000 км. Приблизительно такие же условия должны выполняться для Балтии и Кокчетав-Северо-Тяньшаньской области.

Учитывая изложенные условия, мы попытались очень схематично изобразить взаимное расположение Балтии, Сибири, Кокчетав-Северо-Тяньшаньской области и Чингизской островной дуги в середине силура (рис. 9, $b, c$ ). Сибирь и Балтия расположены на близких широтах, а Кокчетав-Северо-Тяньшаньская область и Чингизская островная дуга расположены на противоположных концах некоей удлиненной структуры, на которой в девоне должен будет сформироваться Казахский вулканический пояс. В промежуток времени между серединой девона и концом карбона эта структура должна была изогнуться до нынешней, петлеобразной формы. Но, как хорошо видно (рис. 9, $b, c)$, имеющиеся палеомагнитные данные позволяют поместить Сибирь к западу от Балтии (рис. 9, $b$ ) или к востоку от нее (рис. 9, $c$ ), таким образом приводя к совершенно разным по «своим последствиям» реконструкциям. Есть доводы в пользу любого из вариантов, есть и доводы против; мы в настоящий момент выбор сделать не можем. Следует также отметить, что можно в широких пределах изменять расстояние между двумя кратонами, просто смещая их по широте, что, в свою очередь, приводит к разным следствиям. Для однозначного же решения проблемы по-прежнему остро не хватает палеомагнитных данных и по кратонам, и по структурам Урало-Монгольского пояса.

\section{6. ЗАКЛЮЧЕНИЕ}

В пределах Чингизской тектонической системы в Северо-Восточном Казахстане было проведено палеомагнитное исследование силурийских и среднедевонских пород. Были выделены высокотемпературные, предположительно первичные, компоненты намагниченности и среднетемпературные, вторичные, компоненты. Направление вторичных компонент совпадает с направлением, пересчитанным для района исследований из пермско-триасовых полюсов Сибири и Балтии. Это говорит о том, что в районе Чингиза в послепермское время не было крупномасштабных присдвиговых блоковых вращений.

Первичные силурийские и девонские направления смотрят на юг, то есть в позднем девоне - среднем карбоне район повернулся на большой угол, около 
$180^{\circ}$, что хорошо согласуется с моделью ороклинального изгибания Казахского вулканического пояса [Abrajevich et al., 2007].

Анализ всех палеомагнитных данных, опубликованных по району Чингизской островной дуги, позволил составить последовательность из девяти палеомагнитных определений, с возрастами, изменяющимися с позднего кембрия до поздней перми. Наблюденные данные хорошо согласуются с ожидаемыми значениями, пересчитанными из полюсов Сибирской платформы. Мы сделали вывод, что движение Чингизской островной дуги было согласовано с движением Сибирской платформы в период с позднего кембрия, по крайней мере, до позднего девона.

\section{7. БЛАГОДАРНОСТИ}

Мы благодарим наших коллег с Научной станции РАН в Бишкеке за помощь в организации полевых работ, Н.Я. Дворову за палеомагнитные измерения, А.В. Шацилло и В.Э. Павлова за разрешение использовать их неопубликованные данные и А.Н. Диденко за конструктивную рецензию первого варианта статьи. Особое спасибо недавно ушедшему от нас Александру Васильевичу Осетрову, который много лет подряд был нашим главным водителем, спокойно и уверенно преодолевал степи, горы и солончаки. Работа выполнена при поддержке Российского фонда фундаментальных исследований, гранты 04-05-64050, 05-05-65105, 07-0500021, 09-05-00260, программы № 9 Отделения наук о Земле PAН и Национального научного фонда США, грант EAR 0335882.

\section{8. ЛИТЕРАТУРА}

Бекжанов Г.Р., Кошкин В.Я., Никитченко И.И., Скринник Л.И., Азизов Т.И., Тимуш А.В. Геологическое строение Казахстана. Алматы: Мин-во природных ресурсов Казахстана, 2000. 395 с.

Богданов А.А. Тектоническое положение палеозоид Центрального Казахстана и Тянь-Шаня // Бюлл. МОИП. Геол. секция. 1965. T. XL. № 5, C. 40-68.

Дегтярев К.Е. Тектоническая эволюция раннепалеозойской активной окраины в Казахстане. М.: Наука, 1999. 124 с.

Дегтярев К.Е., Рязанцев А.В. Проблемы геологии орогенного силура и структуры с непрерывными разрезами в каледонидах Казахстана // Проблемы геологии и металлогении Центрального Казахстана / Под ред. Е.Е. Милановского. М.: Наука, 1993. C. 64-82.

Диденко А.Н., Моссаковский А.А., Печерский Д.М., Руженцев С.В., Самыгин С.Г., Хераскова Т.Н. Геодинамика палеозойских океанов Центральной Азии // Геология и геофизика. 1994. № 7-8. C. 59-75.

Зайцев Ю.А. Эволюция геосиклиналей (овальный концентрическизональный тип). М.: Недра, 1984. 208 с.

Куренков С.А., Диденко А.Н., Симонов В.А. Геодинамика палеоспрединга. М.: ГЕОС, 2002. 294 с.

Курчавов А.М. Закономерности латеральной изменчивости и эволюция орогенного вулканизма складчатых поясов // Геотектоника. 1994. № 2. С. 3-18.

Курчавов А.М. Геодинамическая обстановка проявления девонско- го континентального магматизма Казахстана и юга Западной Сибири // Геология Казахстана и проблемы Урало-Монгольского складчатого пояса / Под ред. Е.Е. Милановского, А.Б. Вейнмара, Ал.В. Тевелева. М.: МГУ, 2001. С. 65-72.

Моссаковский А.А., Руженцев С.В., Самыгин С.Г., Хераскова Т.Н. Центрально-Азиатский складчатый пояс: геодинамическая эволюция и история формирования // Геотектоника. 1993. № 6. C. 3-32.

Пучков В.Н. Палеогеодинамика Южного и Среднего Урала. Уфа: Даурия, 2000. 146 с.

Тевелев Ал.В. Развитие юго-восточной окраины Казахстанского палеоконтинента в познем палеозое // Геология Казахстана и проблемы Урало-Монгольского складчатого пояса / Под ред. Е.Е. Милановского, А.Б. Вейнмара, Ал.В. Тевелева. М.: МГУ. 2001. C. 113-125.

Тектоника Казахстана (Объяснительная записка к Тектонической карте Восточного Казахстана м-ба 1:2500000). М.: Наука, 1982. 139 с.

Турманидзе Т.Л., Гришин Д.В., Печерский Д.М. Палеомагнетизм ордовикских офиолитов из аллохтонных массивов Центрального Казахстана // Геотектоника. 1991. № 4. С. 54-69.

Шацилло А.В., Паверман В.И. Среднепалеозойский участок кривой КМП Сибири: предварительные палеомагнитные результаты по раннему силуру Нюйского фациального района // Палеомагнетизм и магнетизм горных пород. М.: ГЕОС, 2006. С. 165-170.

Щеголева Л.А., Беляев О.Е., Биленко Е.А., Журавлев В.Ю., Кабанов Ю.Ф., Малиновская С.П., Юрина А.Л. Новые данные по корреляции нижне- и среднедевонских вулканических серий в центральном и восточном сегментах Девонского вулканического пояса и прилежащих районах Центрального Казахстана // Геология и металлогения Центрального Казахстана / Под ред. Е.Е. Милановского. М.: Наука, 1993. С. 82-99.

Abrajevitch A.V., Van der Voo R., Levashova N.M., Bazhenov M.L. Paleomagnetism of the mid-Devonian Kurgasholak Formation, Southern Kazakhstan: Constraints on the Devonian paleogeography and oroclinal bending of the Kazakhstan volcanic arc // Tectonophysics. 2007. V. 441. P. 67-84. doi:10.1016/j.tecto.2007.04.008.

Abrajevitch A.V., Van der Voo R., Bazhenov M.L., Levashova N.M., McCausland P.J.A. The role of the Kazakhstan orocline in the late Paleozoic amalgamation of Eurasia // Tectonophysics. 2008. V. 455. P. 61-76. doi:10.1016/j.tecto.2008.05.006.

A geologic time scale 2004 / F.M. Gradstein, J.G. Ogg, A.G. Smith (eds.) / Cambridge: Cambridge University Press, 2004. 589 p. (see www.stratigraphy.org).

Alexyutin M.V., Bachtadse V., Alexeiev D.V., Nikitina O.I. Paleomagnetism of Ordovician and Silurian rocks from the Chu-Yili and Kendyktas mountains, South Kazakhstan // Geophysical Journal International. 2005. V. 162. P. 321-331. doi:10.1111/j.1365-246X. 2005.02533.x.

Bachtadse V., Pavlov V.E., Kazansky A.Y., Tait J.A. Siluro-Devonian paleomagnetic results from the Tuva Terrane (Southern Siberia, Russia): implications for the paleogeography of Siberia // Journal of Geophysical Research. 2000. V. 105. P. 13509-13518. doi:10.1029/ 1999JB900429.

Bazhenov M.L., Burtman V.S., Dvorova A.V. Permian paleomagnetism of the Tien Shan fold belt, Central Asia: the succession and style of tectonic deformation // Tectonophysics. 1999. V. 312. P. 303-329. doi:10.1016/S0040-1951(99)00181-X.

Bazhenov M.L., Collins A.Q., Degtyarev K.E., Levashova N.M., Mikolaichuk A.V., Pavlov V.E., Van der Voo R. Paleozoic northward drift of the North Tien Shan (Central Asia) as revealed by Ordovician and Carboniferous paleomagnetism // Tectonophysics. 2003. V. 366. P. 113-141. doi:10.1016/S0040-1951(03)00075-1.

Burtman V.S., Gurarii G.Z., Belen'kii A.V., Kudasheva I.A. Kazakhstan and the Altai in the Devonian: Paleomagnetic evidence // Geotectonics. 1998. V. 32. № 6. P. 479-487.

Cocks L.R.M., Torsvik T.H. Siberia, the wandering northern terrane, and its changing geography through the Palaeozoic // Earth-Science Reviews. 2007. V. 82. P. 29-74. doi:10.1016/j.earscirev.2007.02. 001. 
Cogné J.P. PaleoMac: a Macintosh application for treating paleomagnetic data and making plate reconstructions // Geochemistry. Geophysics. Geosystems. 2003. V. 4. № 1. 1007. doi:10.1029/2001GC 000227.

Collins A.Q., Degtyarev K.E., Levashova N.M., Bazhenov M.L., Van der Voo R. Early Paleozoic paleomagnetism of East Kazakhstan: implications for paleolatitudinal drift of tectonic elements within the Ural-Mongol belt // Tectonophysics. 2003. V. 377. P. 229-247. doi: 10.1016/j.tecto.2003.09.003.

Degtyarev K.E. Position of the Aqtau-Dzungar microcontinent in the structural framework of the Paleozoides of Central Kazakhstan // Geotectonics. 2003. V. 37. № 4. P. 271-288.

Dobretsov N.L., Berzin N.A., Buslov M.M. Opening and tectonic evolution of the Paleoasian ocean // International Geology Review. 1995. V. 37. P. 335-360. doi:10.1080/00206819509465407.

Filippova I.B., Bush V.A., Didenko A.N. Middle Paleozoic subduction belts: The leading factor in the formation of the Central Asian foldand-thrust belt // Russian Journal of Earth Sciences. 2001. V. 3. № 6. P. 405-426.

Fisher R.A. Dispersion on a sphere // Proceedings of the Royal Society of London. Series A, Mathematical and Physical Sciences. 1953. V. 217. P. 295-305. doi:10.1098/rspa.1953.0064.

Gallet Y., Pavlov V.E. Magnetostratigraphy of the Moyero river section (Northwestern Siberia): a constraint on the geomagnetic reversal frequency during the Early Palaeozoic // Geophysical Journal International. 1996, V. 125. P. 95-105. doi:10.1111/j.1365-246X.1996. b06536.x.

Gallet Y., Pavlov V.E., Courtillot V. Magnetic reversal frequency and apparent polar wander of the Siberian platform in the earliest Palaeozoic, inferred from the Khorbusuonka river section Northeastern Siberia // Geophysical Journal International. 2003. V. 154. P. 829-840. doi:10.1046/j.1365-246X.2003.01996.x.

Grishin D.V., Pechersky D.M., Degtyarev K.E. Paleomagnetic recontruction of the Middle Paleozoic structure of Central Kazakhstan // Geotectonics. 1997. V. 31. № 1. P. 65-75.

Iosifidi A.G., Khramov A N., Rodionov V.P., Pisarevskii S.A., Popov V.V. Geomagnetic reversals in the Early Paleozoic: 2. A Nonsynhronous record of Middle Ordovician reversals in the Berezovskaya section, Southern Siberian platform // Izvestiya, Physics of the Solid Earth. 1999. V. 35. № 1 P. 24-31.

Kheraskova T.N., Didenko A.N., Bush V.A., Volozh Y.A. The VendianEarly Paleozoic history of the continental margin of eastern Paleoondwana, Paleoasian ocean, and Central Asian foldbelt // Russian Journal of Earth Sciences. 2003. V. 5. № 3. 165-184.

Kirschvink J.L. The least-square line and plane and the analysis of palaeomagnetic data // Geophysical Journal of Royal Astronomical Society. 1980. V. 62. P. 699-718. doi:10.1111/j.1365-246X.1980. tb02601.x.

Kravchinsky V.A., Konstantinov K.M., Courtillot V., Savrasov J.I., Valet J.-P., Cherniy S.D., Mishenin S.G., Parasotka B.S. Palaeomagneism of East Siberian traps and kimberlites: two new poles and palaeoeographic reconstructions at about 360 and 250Ma // Geophysical Journal International. 2002. V. 148. P. 1-33. doi:10.1046/j.0956540x.2001.01548.x.

Levashova N.M., Degtyarev K.E., Bazhenov M.L., Collins A.Q., Van der Voo R. Middle Paleozoic paleomagnetism of East Kazakhstan: postMiddle Devonian rotations in a large-scale orocline in the central Ural-Mongol belt // Tectonophysics. 2003a.V. 377. P. 249-268. doi:10.1016/j.tecto.2003.09.013.

Levashova N.M., Degtyarev K.E., Bazhenov M.L., Collins A.Q., Van der Voo R. Permian Paleomagnetism of East Kazakhstan and the Amalgamation of Eurasia // Geophysical Journal International. 2003b. V. 152. P. 677-687. doi:10.1046/j.1365-246X.2003.01879.x.

Levashova N.M., Mikolaichuk A.V., McCausland P.J.A., Bazhenov M.L., Van der Voo R. Devonian paleomagnetism of the North Tien Shan: implications for Middle-Late Paleozoic paleogeography during the assembly of Eurasia // Earth and Planetary Science Letters. 2007. V. 257. P. 104-120. doi:10.1016/j.epsl.2007.02.025.

Levashova N.M., Van der Voo R., Abrajevich A.V., Bazhenov M.L. Paleomagnetism of mid-Paleozoic subduction-related volcanics from the Chingiz range in NE Kazakhstan: The evolving paleogeography of an amalgamating Eurasian supercontinent // Geological Society of America Bulletin. 2009. V. 121. P. 555-573. doi: 10.1130/B26354.1.

Lyons J.J., Coe R.S., Zhao X., Renne P.R., Kazansky A.Y., Izokh A.E., Kungurtsev L.V., Mitrokhin D.V. Paleomagnetism of the early Triassic Semeitau igneous series, Eastern Kazakhstan // Journal of Geophysical Research. 2002. V. 107. № B7. 2139. doi:10.1029/ 2001JB000521.

Mardia K.V. Statistics of directional data. London: Academic Press, 1972. 357 p.

McFadden P.L., McElhinny M.W. The combined analysis of remagneization circles and direct observations in palaeomagnetism // Earth and Planetary Science Letters. 1988. V. 87. P. 161-172. doi:10. 1016/0012-821X(88)90072-6.

Opdyke N.D., Channell J.E.T. Magnetic stratigraphy. International Geophysics Series. V. 64. London - New York: Academic Press, 1996. 346 p.

Pavlov V.E., Courtillot V., Bazhenov M.L., Veselovsky R.V. Paleomagnetism of the Siberian traps: new data and a new overall $250 \mathrm{Ma}$ pole for Siberia // Tectonophysics. 2007. V. 443. P. 72-92. doi:10. 1016/j.tecto.2007.07.005.

Pavlov V.E., Gallet Y. Upper Cambrian to Middle Ordovician magnetostratigraphy from the Kulumbe river section (Northwestern Siberia) // Physics of the Earth and Planetary Interiors. 1998. V. 108. P. 4959. doi:10.1016/S0031-9201(98)00087-9.

Pavlov V.E., Gallet Y. Middle Cambrian high magnetic reversal frequency (Kulumbe river section, Northwestern Siberia) and reversal behavior during the Early Palaeozoic // Earth and Planetary Science Letters. 2001. V. 185. P. 173-183. doi:10.1016/S0012-821X(00) 00364-2.

Pavlov V., Bachtadse V., Mikhailov V. New Middle Cambrian and Middle Ordovician palaeomagnetic data from Siberia: Llandelian magnetostratigraphy and relative rotation between the Aldan and Anabar-Angara blocks // Earth and Planetary Science Letters. 2008. V. 276. P. 229-242. doi:10.1016/j.epsl.2008.06.021.

Pavlov V.E., Shatsillo A.V., Veselovsky R.V. Magnetostratigraphy of the Middle Angara Ordovician section: more evidence in support of the third Phanerozoic superchron // Paleomagnetism and rock magnetism: theory, practice and experiment. Moscow: GEOS, 2003. P. 57-60 (in Russian).

Rodionov V.P., Dekkers M.J., Khramov A.N., Gurevich E.L., Krijgsman W., Duermeijer C.E., Heslop D. Paleomagnetism and cyclostratigraphy of the Middle Ordovician Krivolutsky Suite, Krivaya Luka section, Southern Siberian platform: record of non-synchronous NRM components or a non-axial geomagnetic field? // Studia Geophysica et Geodaetica. 2003. V. 47. P. 255-274. doi:10.1023/ A:1023767523451.

Pisarevsky S.A., Gladkochub D.P., Donskaya T.A., De Waele B., Mazukabzov A.M. Palaeomagnetism and geochronology of mafic dykes in South Siberia, Russia: the first precisely dated Early Permian palaeomagnetic pole from the Siberian craton // Geophysical Journal International. 2006. V. 167. P. 649-658. doi:10.1111/j.1365246X.2006.03160.x.

Pisarevsky S.A., Gurevich E.L., Khramov A.N. Paleomagnetism of Lower Cambrian sediments from the Olenek river section (Northern Siberia): paleopoles and the problem of magnetic polarity in the Early Cambrian // Geophysical Journal International. 1997. V. 130. P. 746-756. doi:10.1111/j.1365-246X.1997.tb01869.x.

Şengör A.M.C., Natal'in B.A. Paleotectonics of Asia: fragments of a synthesis // The tectonic evolution of Asia. Cambridge: Cambridge University Press, 1996. P. 486-640.

Smethurst M.A., Khramov A.N., Pisarevsky S.A. Palaeomagnetism of the Lower Ordovician Orthoceras Limestone, St. Petersburg, and a revised drift history for Baltica in the Early Palaeozoic // Geophysical Journal International. 1998a. V. 133. P. 44-56. doi:10.1046/j. 1365-246X.1998.1331463.x.

Smethurst M.A., Khramov A.N., Torsvik T.H. The Neoproterozoic and Paleozoic paleomagnetic data for the Siberian platform: from Rodinia to Pangea // Earth-Science Reviews. 1998b. V. 43. P. 1-24. doi: 
10.1016/S0012-8252(97)00019-6.

Stampfli G.M., Borel G.D. A plate tectonic model for the Paleozoic and Mesozoic constrained by dynamic plate boundaries and restored synthetic oceanic isochrones // Earth and Planetary Science Letters. 2002. V. 196. P. 17-33. doi:10.1016/S0012-821X(01)00588-X.

Surkis Yu. F., Westfahl M., Rodionov V.P., Khramov A.N., Gurevich E.L. Geomagnetic reversals in the Early Paleozoic: 3. - reversals recorded in redbeds of the Lower Ordovician Mandra section, Siberia // Izvestiya, Physics of the Solid Earth. 1999. V. 35. № 5. P. 347-357.

Torsvik T.H., Tait J., Moralev V.M., McKerrow W.S., Sturt B.A., Roberts $D$. Ordovician paleogeography of Siberia and adjacent continents // Journal of Geological Society of London. 1995. V. 152. P. 279-287. doi:10.1144/gsjgs.152.2.0279.

Van der Voo R. Paleomagnetism of the Atlantic, Tethys and Iapetus oceans: Cambridge: Cambridge University Press, 1993. 411 p.

Van der Voo R., Levashova N.M., Skrinnik L.I., Kara T.V., Bazhenov
M.L. Late orogenic, large-scale rotations in the Tien Shan and adjacent mobile belts in Kyrgyzstan and Kazakhstan // Tectonophysics. 2006. V. 426. P. 335-360. doi:10.1016/j.tecto.2006.08.008.

Yakubchuk A., Cole A., Seltmann R., Shatov V.V. Tectonic setting, characteristics, and regional exploration criteria for gold mineralization in the Altaid tectonic collage: the Tien Shan province as a key example // Society of Economic Geologists, Special Publications. 2002. V. 9. P. 177-201.

Yakubchuk A.S., Seltmann R., Shatov V.V., Cole A. The Altaids: tectonic evolution and metallogeny // Society of Economic Geologists Newsletter. 2001. V. 46, P. 7-14.

Zijderveld J.D.A. AC demagnetization of rocks: analysis of results // Methods in Paleomagnetism. Amsterdam: Elsevier, 1967. P. 254286.

Zonenshain L.P., Kuzmin M.I., Natapov L.M. Geology of the USSR: a plate-tectonic synthesis: Washington, D.C.: Amer. Geophys. Union, Geodynamics Series. 1990. V. 21. 242 p.
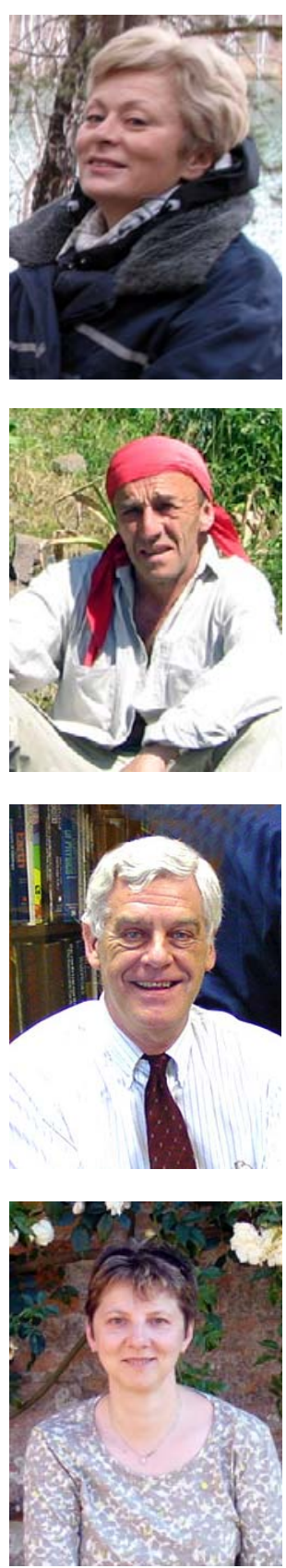

Левашова Наталья Михайловна, канд. геол.-мин. наук, н. с.

Геологический институт РАН

119017, Москва, Пыжевский пер., 7, Россия

e-mail: namile2007@rambler.ru

Levashova, Natalia M., Candidate of Geology and Mineralogy, Senior Researcher

Geological Institute of RAS

119017, Moscow, Pyzhevsky Lane, 7, Russia

e-mail: namile2007@rambler.ru

Баженов Михаил Львович, докт. геол.-мин. наук, зав. лаб. палеомагнетизма

Геологический Институт РАН

119017, Москва, Пыжевский пер., 7, Россия

$\triangle$ e-mail:mibazh@mail.ru

Bazhenov, Mikhail L., Doctor of Geology and Mineralogy, Head of Palaeomagnetism Laboratory Geological Institute of RAS

119017, Moscow, Pyzhevsky Lane, 7, Russia

$\triangle$ e-mail: mibazh@mail.ru

Ван дер Во Роб, профессор геологии

Департамент геологических наук Мичиганского университета

48109-1005, Энн Эрбор, Мичиган, США

e-mail:voo@umich.edu

Van der Voo, Rob, Frank H.T. Rhodes Professor of Geological Sciences

Department of Geological Sciences, University of Michigan

48109-1005, Ann Arbor, Michigan, USA

e-mail:voo@umich.edu

Абражевич Александра Владимировна, Ph.D

Исследовательская школа наук о Земле, Австралийский национальный университет

АСТ 0200, 11, Канберра, Австралия

e-mail: alexandra.abrajevitch@gmail.com

Abrajevitch, Alexandra V., Ph.D.

Research School of Earth Sciences, The Australian National University

ACT 0200, 11, Canberra, Australia

e-mail: alexandra.abrajevitch@gmail.com 